\title{
Protective face masks: current status and future trends
}

Alberto Tuñón-Molina ${ }^{1,2}$, Kazuo Takayama ${ }^{3}$, Elrashdy M. Redwan ${ }^{4}$, Vladimir N. Uversky $^{5}$, Juan Andrés ${ }^{6}$ and Ángel Serrano-Aroca, ${ }^{2, *}$

${ }^{1}$ Doctoral school, Universidad Católica de Valencia San Vicente Mártir, c/Guillem de Castro 94, 46001 Valencia, Valencia, Spain.

${ }^{2}$ Biomaterials and Bioengineering Lab, Centro de Investigación Traslacional San Alberto Magno, Universidad Católica de Valencia San Vicente Mártir, c/Guillem de Castro 94, 46001 Valencia, Valencia, Spain.

${ }^{3}$ Center for iPS Cell Research and Application (CiRA), Kyoto University, Kyoto 6068507, Japan

${ }^{4}$ Faculty of Science, Department of Biological Science, King Abdulaziz University, Jeddah 21589, Saudi Arabia

${ }^{5}$ Department of Molecular Medicine, Morsani College of Medicine, University of South Florida, Tampa, FL 33612, USA

${ }^{6}$ Department of Physical and Analytical Chemistry, University Jaume I (UJI), 12071 Castellon, Spain 


\begin{abstract}
The COVID-19 pandemic, caused by severe acute respiratory syndrome coronavirus 2 (SARS-CoV-2), has stressed the importance of the use of personal protective of personal protective equipment (PPE). In the present time, face masks, as representative example of PPE, demonstrated useful significant contribution in COVID-19 pandemic management effectively. However, these commonly used face masks are made of materials without inactivation properties against either SARS-CoV-2 or multidrugresistant bacteria. Therefore, symptomatic and asymptomatic individuals can infect other people even if they wear them since some viable microbial loads can escape from the masks. Furthermore, microbial contact transmission can occur by touching the mask, and they are an increasing source of contaminated biological waste. In this regard, during the current pandemic, many researchers have been working on the development of face masks made of advanced materials with intrinsic antimicrobial properties to avoid these problems, and thus provide extra protection against pathogens. In this dazzling race against COVID-19, this review presents the types of commercialized face mask, their main fabrication methods and treatments, and the progress achieved in the development of smart antimicrobial face masks.
\end{abstract}

Keywords: SARS-CoV-2; coronavirus; COVID-19; face mask; smart materials; antimicrobial; aerosol; antimicrobial; bacterial filtration; breathability. 


\section{Introduction}

An unprecedented coronavirus (SARS-CoV-2) was first reported in Wuhan, China, in December 2019 (ref. [1]), causing the coronavirus disease 2019 (COVID-19) pandemic. SARS-CoV-2 has led to a global pandemic that has resulted in more than three million deaths around the globe[2]. SARS-CoV-2 can be found in bats[3] and is easily transmitted from human to human[3]. Human coronaviruses (HCoVs) are usually transmitted via respiratory droplets, but aerosol, direct exposure to polluted surfaces, or fecal-oral transmission were also described during the SARS epidemic[4-6]. Direct exhibition of aerosol particles and beads produced during coughing or sneezing from symptomatic or asymptomatic patients is the predominant way of transmission of SARS-CoV-2[7]. Indirect contact with tainted surfaces is the second principal route of transmission[8,9] (Figure 1). This occurs due to the droplets generated while sneezing and coughing, which can spread 1-2 $\mathrm{m}$ and accumulate on surfaces[10].

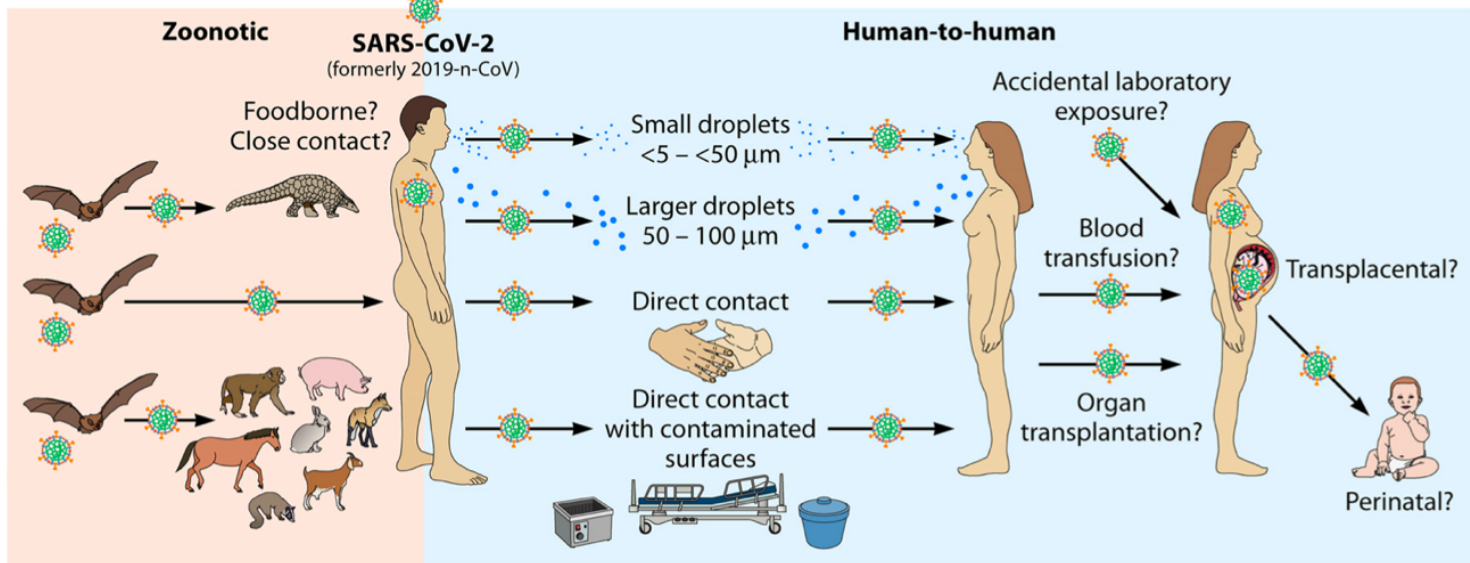

Figure 1. Transference routes for SARS-CoV-2 (from Dhama et al.[11])

SARS-CoV-2 can remain viable on worktops between hours and days, depending on the type of surfaces and environmental conditions[12]. The persistence of SARS-CoV-2 was studied within 3 hours aerosolization time at room temperature $\left(21-23^{\circ} \mathrm{C}\right)$ and a fixed relative humidity of $65 \%$, and the virus was discernible after 3 hours of aerosolization[13]. The average half-life was measured at $65 \%$ relative humidity and $21-$ $23^{\circ} \mathrm{C}$. Aerosols $(<5 \mu \mathrm{m})$ composed of SARS-CoV-2 $\left(10^{5.25} \mathrm{TCID}_{50} / \mathrm{mL}\right)$ were generated into a Goldberg drum to create an aerosolized environment and testing samples were gathered at $0,30,60,120$, and 180 minutes post-aerosolization. This experiment resulted in a half-life estimation of 1.09 hours[13]. A different study showed that aerosolized SARS-CoV-2 conserved its infectious activity for a duration of 16 hours at room 
temperature[14]. However, on plastic surfaces such as polystyrene, polyvinyl chloride (PVC), or teflon, this virus can persist and retain its infectivity for 3-4 days[13,15,16]. On stainless steel surfaces, SARS-CoV-2 persists for 3 days but becomes undetectable after 4 days[13], while on glass the virus stays infectious for 2 days[15]. Preservation of the influenza A virus was also studied on personal protective equipment (PPE) like gloves, gowns, visors, or face masks [17]. Influenza A (H1N1) virus was found to be infectious after 8 hours on all aforementioned surfaces at $25.2^{\circ} \mathrm{C}$ and $55 \%$ relative humidity[17]. Due to this kind of study, the permanence of SARS-CoV-2 in PPE was also studied[18]. It was found that a virus dosage of $10 \mu \mathrm{L}$ of $10^{7.88} \mathrm{TCID}_{50} / \mathrm{mL}$ was still detectable on nitrile gloves or face masks after 7 days[18,19], 4 days on chemical-resistant gloves (typically manufactured with nitrile rubber[20]), 21 days on plastic face masks, and 14 days on Tyvek and stainless steel under environmental conditions[18]. All these discoveries led many countries to adopt measures against the illness caused by the SARSCoV-2 (COVID-19) transmission. Frequent washing of hands, social distancing, closed space ventilation, and use of face masks, among others, became crucial means of COVID19 prevention[21]. However, a great controversy was thrown up about face mask use at the beginning of the pandemic[22]. According to World Health Organization (WHO) guidelines published in January and March 2020[23,24], asymptomatic individuals did not have the obligation of wearing face masks unless they were in close contact with contaminated individuals. In April 2020, a WHO report[25] expressed that there was no statement that wearing a mask (medical or otherwise) if you were in good health would help avoid contagion of SARS-CoV-2, and did not reach a decision or conceive any suggestions for or against its usage. Despite this WHO advice, some countries such as China, South Korea, Japan, and the Czech Republic implemented the utilization of face masks from the beginning[22]. In different countries, health authorities abstained from making recommendations regarding the face mask issue at the beginning. That was the case in countries such as the UK, Germany, Spain, and Mexico[26]. In contrast, on April $4^{\text {th }}, 2020$ the Centers for Disease Control and Prevention (CDC) recommended people to wear cloth masks of domestic manufacture in public areas, and included directions on how to produce and wear them[27]. Eikenberry et al. [28] devised a mathematical model using data applicable to COVID-19 transmission in two US states (New York and Washington) and suggested robust welfares to widespread face mask utilization, with increasing advantages when combined with other measures such as social distancing or self-isolation. Cheng et al.[29] remarked in their study that in the Hong Kong Special 
Administrative Region of China (HKSAR), wearing face masks for general public was carried out by population at an early stage of the SARS-CoV-2 pandemic. Due to the SARS epidemic experience, the general population of HKSAR was in alarm after the communication of pneumonia cases of unascertained origin in Wuhan, China. This led them to make and wear cloth masks from the beginning in order to prevent the spread of the disease[29]. In their study, Cheng et al. found that COVID-19 incidence was significantly lower within the first 100 days in HKSAR (129.0 per million population) than that in other countries such as Spain (2983.2), Italy (2250.8), Germany (1241.5), or France (1151.6), where putting on a face mask was not recommended at the start of the pandemic. All this controversy may be explained due to asymptomatic infections[30] and the discovery of the transmission ways for SARS-CoV-2[4-6]. At first, it was thought that asymptomatic carriers were a minimum amount of people and even that they could not infect other people[31]. However, since February 2020, there have been reports of people getting infected with SARS-CoV-2 that had no symptoms of the COVID-19 disease[32,33]. In those asymptomatic patients, for the most part, the viral load has been equal to that of symptomatic people[34,35], which suggests a similar potential of transmission[30]. The discovery of aerosol transmission[7] became a call for scientists and healthcare workers due to the ease of spread for SARS-CoV-2 even for asymptomatic patients. As explained above, aerosol or direct contact are the main routes of SARS-CoV2 transmission[7]. These ways could be more likely than fecal-oral transmission as explained by Hussain et al.[36]. There are also reports corroborating that SARS-CoV-1 spreads through the air as the principal transmission route in certain indoor circumstances and discerning the possibility of similar transference for the novel coronavirus[37]. To take precautionary steps to control SARS-CoV-2 conveyance, it has been stated that particles comprising the virus can reach up to $10 \mathrm{~m}$ from a transmitter in indoor environments[38,39] (Figure 2). 


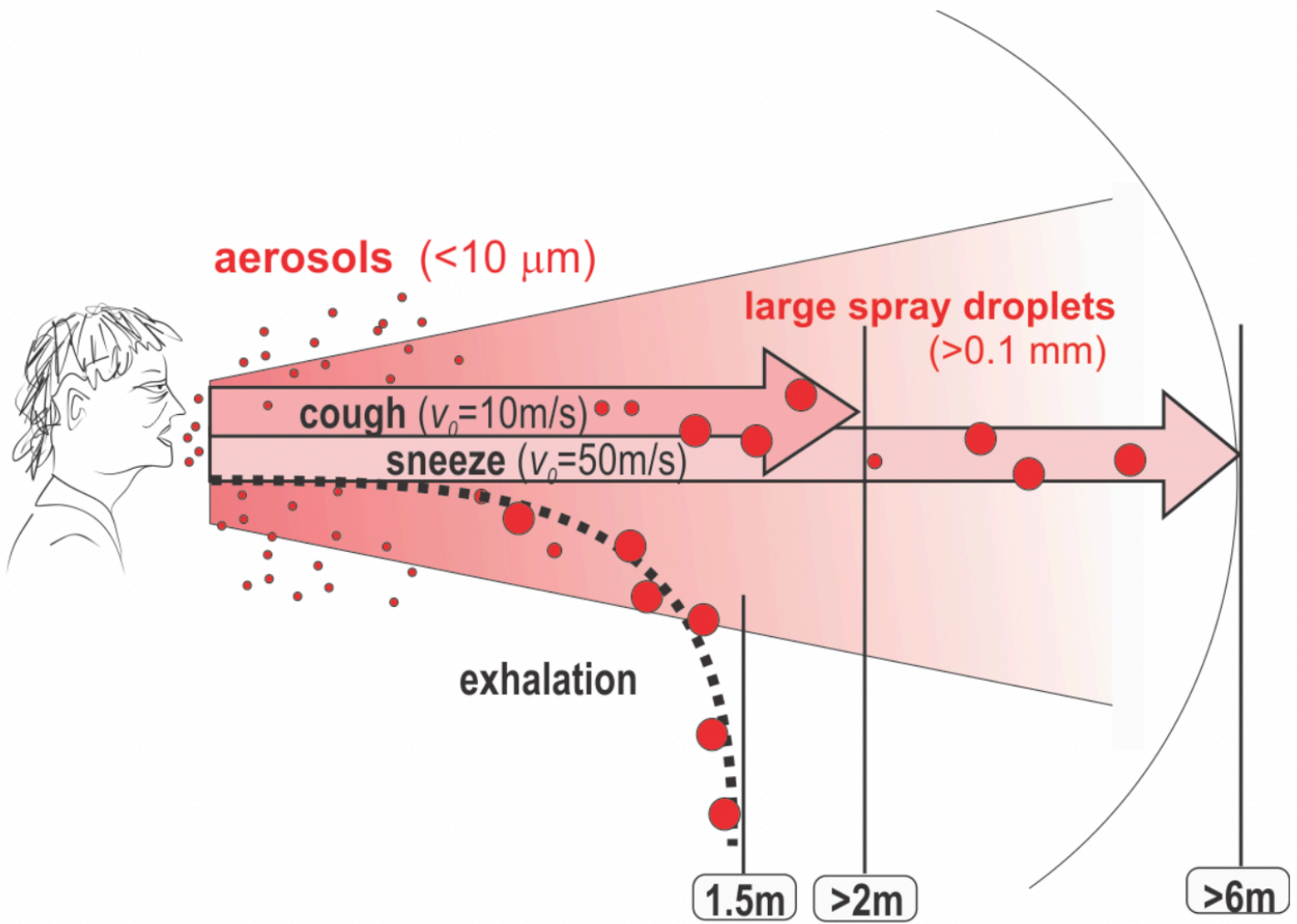

Figure 2. Droplets of greater size than aerosols, when breathed out (at speed $<1 \mathrm{~m} / \mathrm{s}$ ), vaporize or fall down less than $1.5 \mathrm{~m}$ away. When emitted at high rapidity through coughing or sneezing, bigger droplets can be ejected more than 2 or $6 \mathrm{~m}$ away, respectively (from Huang, S.[40])

That is the main reason why natural freshening and evading air recirculation should be put into practice in these places[37,38]. Li et al.[41] described a situation where aerosol transmission of SARS-CoV-2 due to bad ventilation in a Chinese restaurant could explain a COVID-19 outbreak occurring in three non-associated families. On February 2020 WHO pointed out that the proportion of truly asymptomatic patients of COVID-19 was reasonably unimportant and was not dominant via virus extension[42]. In contrast to this state, a study published that in a distant village in northern Italy of around 3,000 people, $50-75 \%$ of people with a positive diagnose for COVID-19 were completely asymptomatic[43]. Moreover, this finding was supported with a different work where it was shown that among 166 people who tested positive for SARS-CoV-2 disease in China arriving from abroad, 78\% were asymptomatic[44]. All this evidence pointed out the importance of limiting aerosol spreading from not only symptomatic patients but also asymptomatic carriers to control the spread of the virus, and so face masks became an important tool in pandemic control. Filters composed of ultrafine fibers with diameter lower than 10 nanometers have the potential to physically block viruses and bacteria[45]. Furthermore, the composition and nanostructure of these filters can be tailored to achieve 
other important functions such as antimicrobial activity, transparency and degradability, and highlights the importance of materials science and nanotechnology research on tackling microbial diseases such as COVID-19[46-51]. Thus, in this systematic review, we present the most important types of commercial face masks, classified according to their breathability, bacterial filtration efficiency (BFE), or inward leakage, and the new trend towards the development of advanced antimicrobial face masks or smart masks capable of inactivating a virus such as SARS-CoV-2 and bacteria, including the multidrug-resistant strains. The review also covers the conventional fabrication methods of conventional and antimicrobial face masks, which are currently very promising to combat the COVID-19 spread.

\section{Fabrication methods and treatments of face mask fabrics}

The main fabrication methods and treatments of face mask fabrics such as meltblowing, spunbonding, electrospinning (Figure 3), and dip-coating are presented in the following subsections.

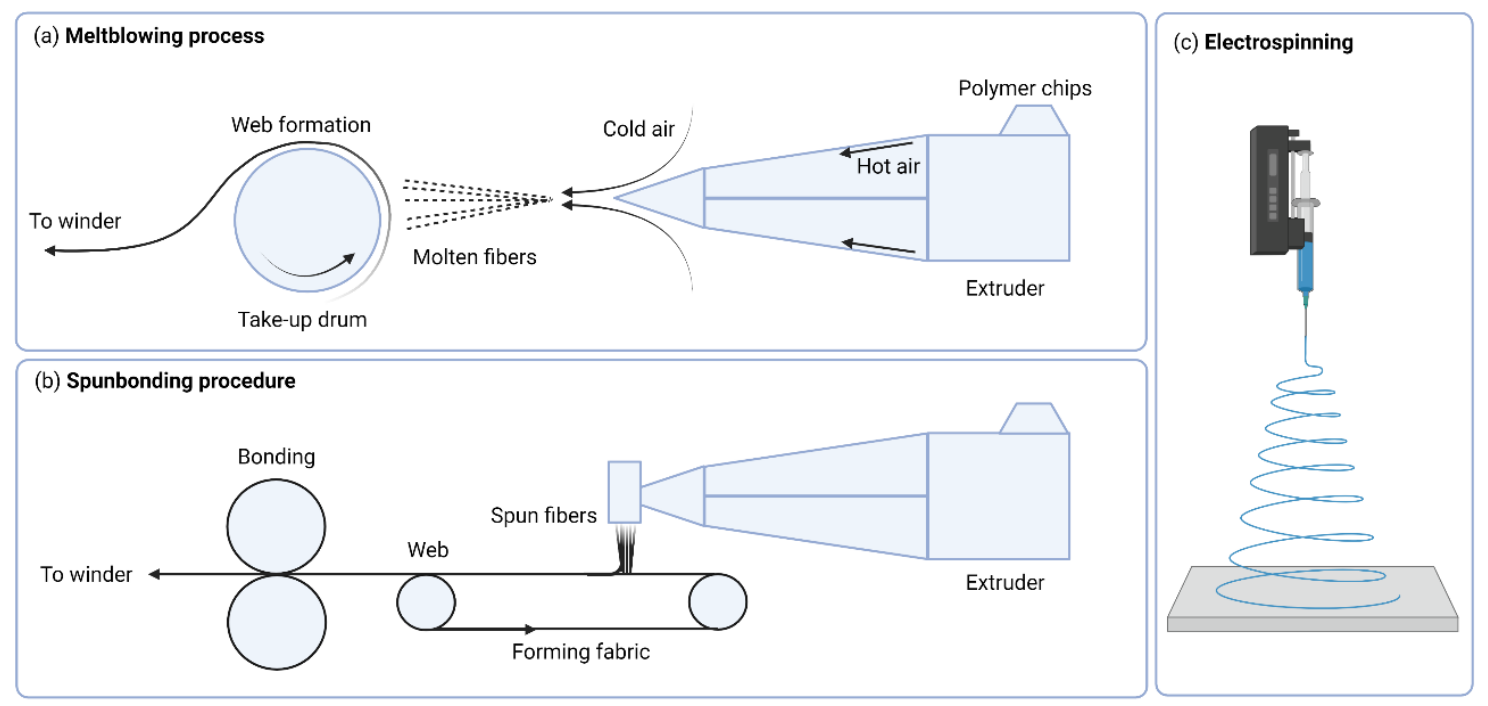

Figure 3. Schematic of meltblowing (a), spunbonding (b) and electrospinning (c) processes.

\subsection{Meltblowing}

Meltblowing is a fabrication method of micro- and nano-fibers where a polymer or resin is melted and extruded through hundreds of small nozzles (Figure 3a).

A high-speed blowing gas is used to deposit fibers in a conveyor and forms a nonwoven web with fibers deposited in a random way[52,53]. Materials such as polystyrene, 
polycarbonate, polyester, or polyethylene are suitable for this method. As a result of this procedure, fibers with small diameters $(1-5 \mu \mathrm{m})$ and pores with smaller sizes are manufactured. These kinds of sheets are used for the fabrication of high-quality face masks, respirators, or cleaning room filters[52,53].

\subsection{Spunbonding}

During spunbonding, a melted polymer is projected to a conveyor belt (Figure 3b). After this, fibers are linked together by heating or chemical or mechanical methods to form the nonwoven fabric. Then, the fabric is wrapped on a reel by the winder[53]. This kind of fabric is characterized by having a fiber diameter fluctuating between 1 to $50 \mu \mathrm{m}$. Polymers as polypropylene, polyester, polyethylene, or polyurethane are appropriate for this procedure, although isotactic polypropylene is the most widely used[52,53].

\subsection{Electrospinning}

Electrospinning is characterized by using an electric field to discharge the polymer solution (Figure 3c). As the polymer goes through the electromagnetic field, it becomes finer and is accumulated on a flat surface generating a nanofibrous nonwoven net[52,53]. It has been stated that the diameter of fibers formed by this method is about 100-500 nm, where differences can be found caused by electrostatic forces or polymers' viscoelasticity[53]. Polymers like polyvinyl pyrrolidone, polyvinyl alcohol, polyacrylonitrile, or polystyrene are suitable for electrospinning. Moreover, biocompatible and biodegradable polymers are also appropriate, such as polylactic $\operatorname{acid}[52-54]$

\subsection{Dip-coating}

Dip-coating is an easy and cost-effective method to produce and treat non-woven fabrics. It consists of an accumulation of a thin, uniform layer of a mixture containing metallic particles, biomolecules, or polymer fibers to create a covering coat on the substrate (Figure 4). 


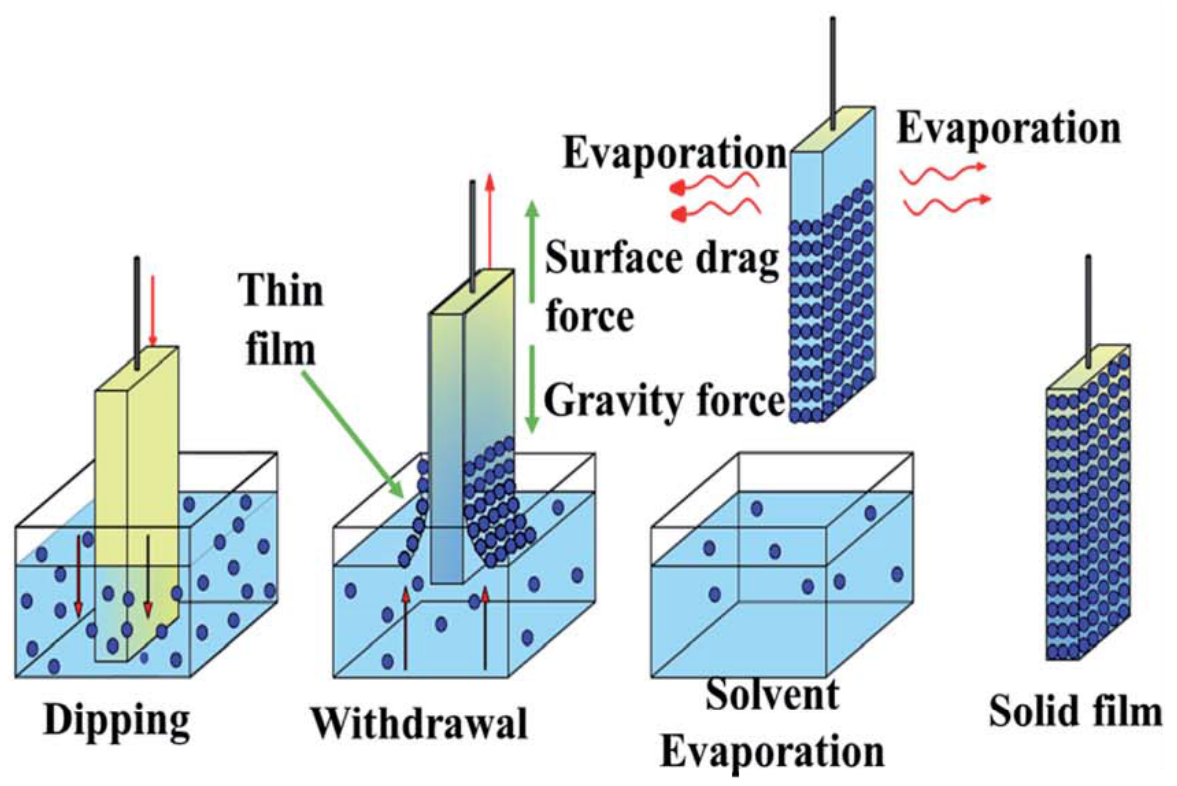

Figure 4. Schematic of dip-coating process (from Pullangott et al. [52])

The dip-coating process is divided into five different phases: material submersion, startup, and displacement, followed by seepage and evaporation[52]. This procedure is appropriate for horizontal or plane surfaces, but is not suitable for coating a unique side of an item[52].

\section{Face mask types}

The most important face mask types are shown in Figure 5. 


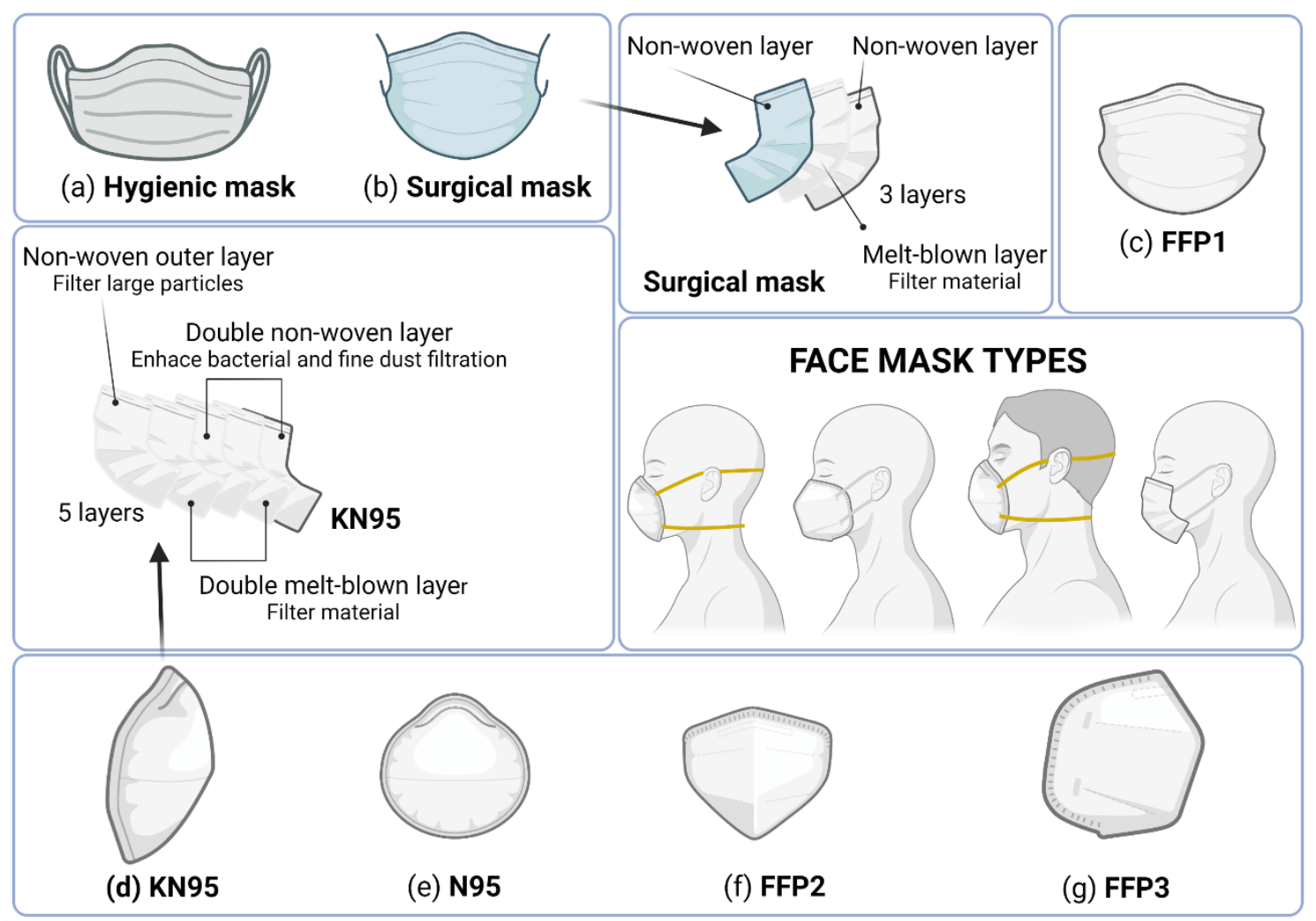

Figure 5. Different types of face masks commercially available worldwide: a) Hygienic face mask; b) Surgical face masks design; c) FFP1 face mask; d) KN95 face mask; e) N95 face mask; f) FFP2 face mask; g) FFP3 face mask

They are protective tools made to use by the population to avoid the transmission of pollutants and/or biological infectious particles. A summary of the different categories of face masks commercialized internationally according to their material, breathability, bacterial filtration level, and internal leak rate is provided in Table $\mathbf{1 .}$

Table 1. Types of face masks.

\begin{tabular}{|c|c|c|c|c|c|}
\hline Face & Material & Breathability & $\begin{array}{c}\text { Bacterial } \\
\text { filtration }\end{array}$ & $\begin{array}{c}\text { Internal } \\
\text { leak rate }\end{array}$ & Ref. \\
\hline FFP1 & Flexible paper & No data available & $\geq 80 \%$ & $<2 \%$ & {$[71-80]$} \\
\hline FFP2 & $\begin{array}{c}\text { Non-woven spunbond and } \\
\text { meltblown fabric. Sometimes } \\
\text { they include a PP cotton layer. }\end{array}$ & No data available & $\geq 94 \%$ & $<8 \%$ & $\begin{array}{c}{[71-} \\
{[6],}\end{array}$ \\
\hline KN95 & $\begin{array}{c}\text { Non-woven fabric, hot air } \\
\text { cotton and meltblown fabric }\end{array}$ & No data available & $\geq 95 \%$ & $<8 \%$ & {$[85]$} \\
\hline FFP3 & $\begin{array}{c}\text { Non-woven spunbond and } \\
\text { meltblown fabric. Sometimes } \\
\text { they include a PP cotton layer. }\end{array}$ & No data available & $\geq 99 \%$ & $<2 \%$ & $\begin{array}{c}76], \\
{[80],} \\
{[82]}\end{array}$ \\
\hline Hygienic & $\begin{array}{c}\text { Five layers of non-woven } \\
\text { fabric }\end{array}$ & $<60$ Pa/cm ${ }^{2}$ & $\geq 95 \%$ & $\begin{array}{c}\text { No data } \\
\text { available }\end{array}$ & {$[52-57]$} \\
\hline
\end{tabular}




\begin{tabular}{|c|c|c|c|c|}
\hline $\begin{array}{c}\text { Surgical } \\
\text { type I }\end{array}$ & $\begin{array}{c}\text { Non-woven and meltblown } \\
\text { fabric }\end{array}$ & $<40 \mathrm{~Pa} / \mathrm{cm}^{2}$ & $\geq 95 \%$ & $\begin{array}{c}\text { No data } \\
\text { available }\end{array}$ \\
$\begin{array}{c}\text { [47], } \\
{[58-70]}\end{array}$ \\
$\begin{array}{c}\text { Surgical } \\
\text { type II }\end{array}$ & $\begin{array}{c}\text { Non-woven and meltblown } \\
\text { fabric }\end{array}$ & $<60 \mathrm{~Pa} / \mathrm{cm}^{2}$ & $\geq 98 \%$ & $\begin{array}{c}\text { No data } \\
\text { available }\end{array}$ \\
{$\left[\begin{array}{c}{[47],} \\
{[58-70]}\end{array}\right.$} \\
\hline $\begin{array}{c}\text { Surgical } \\
\text { type IIR }\end{array}$ & $\begin{array}{c}\text { Non-woven and meltblown } \\
\text { fabric }\end{array}$ & $<60 \mathrm{~Pa} / \mathrm{cm}^{2}$ & $\geq 98 \%$ & $\begin{array}{c}\text { No data } \\
\text { available } \\
{[58-70]}\end{array}$ \\
\hline
\end{tabular}

The American Society of Testing and Materials (ASTM) F2100 standard specifies the performance criteria for materials used for the fabrication of commercial face masks[55]. Thus, since face masks provide protection against airborne particles, pathogenic microorganisms, secretions, and body fluids by physically impede their pass from breathable air, several material performance characteristics have to be analyzed: particulate filtration efficiency (PFE), bacterial or viral filtration efficiency (BFE) using a six-stage Andersen sampler (see Figure 7 in Ref.[56]), fluid resistance, differential pressure, and flammability. Another parameters used for mask manufacturers is the viral filtration efficiency (VFE) that can be measured also with the Andersen sampler. Moreover, when face masks are made of materials or contain any chemical compound that may be toxic for humans, cytoxicity tests are recommended to be performed according to the Norm ISO-10993 standard[57].

\subsection{Hygienic masks}

Hygienic masks (see Figure 5a) are usually manufactured with five layers of non-woven fabric[58]. These masks include two layers of non-woven spunbond fabric in the outer side of the mask, two layers of non-woven spunlace fabric and, finally, one layer of nonwoven spunbond fabric in the interior side[58]. Due to the situation experienced worldwide caused by the SARS-CoV-2 pandemic, new systems and products are being used as an impediment for virus transmission, together with social distance measures[59]. This is the case of hygienic face masks, which cannot be considered a piece of sanitary equipment according to UE/2017/745 regulation, or a piece of personal protective equipment according to UE/2016/425 regulation[60]. There are some regulations that hygienic mask manufacturers must follow related to materials used in their production or usage: UNE 0064-1:2020 deals with requirements of materials, design, and usage of hygienic face masks in adults[61]; UNE 0064-2:2020 specifies the same as UNE-EN 0064-1:2020 but pertains to children[62]; and UNE 0065:2020 concerns the requirements of materials, design, and usage of reusable hygienic face masks in adults and children[63]. 
Hygienic face masks provide their users with a bacterial filtration efficiency equal to or greater than $95 \%$ in the case of disposable masks, or equal to or greater than $90 \%$ for reusable ones[59]. They also offer a breathability of $<60 \mathrm{~Pa} / \mathrm{cm}^{2}$ [59]. These two conditions make these masks a double-protective barrier (inside-outside and outsideinside)[60] that allow users to carry on with everyday life while being protected.

\subsection{Surgical masks}

Surgical masks (see Figure 5b) are usually manufactured following the 3-ply (three layers) design, with two layers of non-woven fabric including a meltblown fabric between them[64]. The meltblown layer is the one that provides this kind of mask with its filtering activity[65]. Surgical face masks are made to supply their users with an impediment to splatters and droplets that collide with the wearer's nose, oral cavity, or respiratory tract[66]. Surgical face masks are not classified as respiratory protection equipment (RPE) because they do not offer screens against aerosol particle infection[67]. However, this kind of mask is made to prevent wearers from contamination of the surrounding environment, as they minimize the transmission of infectious agents outside the mask[68]. To be considered safe to use, surgical face masks must be manufactured according to the following technical regulations: UNE-EN 14683:2019, which specifies requirements about structure, design, operation requirements, and essay methods[69]; UNE-EN ISO 10993-1:2010 that determines the technical criteria for the biological evaluation of healing devices[70]; UNE-EN ISO 11737-1:2018, about the determination of microorganism populations on products[71]; UNE-EN ISO 15223-1:2017, regarding icons to be used on tags of medical devices and data to be provided[72]; and UNE-EN 1041/2009 \& A1:2014, which clarifies essentials to be provided by the fabricator on sanitary equipment [73]. All these technical criteria make surgical face masks be able to be evaluated according to requirements such as bacterial filtration efficiency (BFE), breathability, splash resistance, or microbial cleanliness[68].

A study of the interactions of the incoming droplets over 3-layer surgical masks in terms of wetting signature, adhesion, and impact dynamics of water droplets and microbe-laden droplets have shown similar interfacial characteristics for the front and the back side of the mask[74]. According to regulation UNE-EN 14683:2019 \& AC:2019[69] about surgical face masks, we can find three distinct categories of surgical masks as a result of 
comparing their bacterial filtration efficiency, differential pressure, splash resistance pressure, and bacterial load (see Table 2).

Table 2. Requirements for different types of surgical face masks. (Adapted from Santarsiero et al. 2020 ref.[68]).

\begin{tabular}{|c|c|c|c|}
\hline \multicolumn{4}{|c|}{ SURGICAL FACE MASKS } \\
\hline ESSAY & TYPE I & TYPE II & TYPE IIR \\
\hline Bacterial filtration efficiency $(\mathrm{BFE}) \%$ & $\geq 95$ & $\geq 98$ & $\geq 98$ \\
\hline Differential pressure $\left(\mathrm{Pa} / \mathrm{cm}^{2}\right)$ & $<40$ & $<60$ & $<60$ \\
\hline Splash resistance pressure $(\mathrm{kPa})$ & - & - & $\geq 16$ \\
\hline Bacterial load (UFC/g) & $\leq 30$ & $\leq 30$ & $\leq 30$ \\
\hline
\end{tabular}

Type I surgical face masks should be used only by sick individuals with intention of decreasing the risk of transmission of infections, primarily during an epidemic or a pandemic[68]. Nevertheless, the dimensions and density of SARS-CoV-2 in aerosols produced during coughing or sneezing are still unknown[75], and some authors observed that surgical masks may not be able to adequately filter particles generated in aerosols measuring 0.9, 2.0, and 3.1 $\mu \mathrm{m}[76]$. Lee et al. demonstrated that particles 0.04 to $0.2 \mu \mathrm{m}$ can pass through surgical mask filters[77], and, presuming that SARS-CoV-2 has comparable dimensions to SARS-CoV (0.08 to $0.14 \mu \mathrm{m}[78])$, it is plausible to think that surgical masks are improbable to successfully filter this new coronavirus[75].

\subsection{FFP Masks}

Filtering face masks are used by individuals to supply them with respiratory protection[66]. The European standard for filtering face masks lists three classes of filtering face pieces (FFP): FFP1, FFP2, and FFP3[79] (see Table 1). FFP masks are often manufactured following the spunbond-meltblown-spunbond (SMS) rule[80]. This means that the basic diagram for this kind of mask is made with three layers: two non-woven spunbond fabric layers in the outer and interior side of the mask, and a non-woven meltblown fabric layer in the middle of the spunbond films[81]. Sometimes FFP masks also include a PP cotton layer between the outer spunbond layer and the meltblown sheet[80]. 
FFP masks are produced to protect their users from toxic particle or pathogen inhalation [82]. This kind of protection is regulated by personal protective equipment rules (UE 2016/425 regulation)[83] and their technical standards are detailed in UNE-EN 149:2001 and A1:2010 regulation[84], which specifies information about particles leakage, inflammability, or carbon dioxide content, among others.

\subsubsection{FFP1}

FFP1 masks (Figure 5c) are usually made of flexible paper to offer protection and comfort to users against non-toxic powders[85-87]. They are used in environments where high amounts of dust are raised into the air, usually involving activities such as construction, cleaning, or sweeping[86,87]. They do not protect against hazardous dusts, gases, or vapors[86,87]. FFP1 masks provide their users with an aerosol filtration of at least $80 \%$, and their internal leak rate is less than $22 \%$ [88].

\subsubsection{FFP2}

FFP2 masks (Figure 5f) are the most widely used facial-covering accessories in healthcare[89]. These kinds of masks are high-filtration masks that intend to filtrate at least $94 \%$ of scraps as petite as 0.3-0.6 $\mu \mathrm{m}$ in diameter[90]. FFP2 masks can filtrate 98.8$99.8 \%$ of particles measuring $0.04-150 \mu \mathrm{m}$ in diameter[91]. The fact that respiratory viruses move through the air in aerosols linked to the effective filtration capacity of FFP2 masks explains their excellent viral protection despite pulmonary viruses (together with SARS-CoV-2) being smaller than the filtration standard[91]. FFP2 masks provide an aerosol filtration $\geq 94 \%$ and their inward leakage is $<8 \%$ [88]. FFP2-type filtering masks should be saved for healthcare employees when carrying out medical strategies on the respiratory tract or other procedures with a risk of generating aerosols[92].

\subsubsection{KN95 and N95}

KN95 face masks (Figure 5d and 5e) are manufactured according to standards for FFP masks that are guaranteed in China and the United States, respectively. KN95 maks are controlled by the Chinese government under regulations GB2626-2006, GB262-2019, and GB19083-2010. KN95 masks provide users with five-layer protection. Layers are 
made from non-woven fabric, hot air cotton, and meltblown fabric[93]. Under these regulations, KN95 face masks offer a $\geq 95 \%$ protection against particles bigger than $0.3 \mu \mathrm{m}$ and an internal leakage lower than $8 \%$. It is important to mention that requisites for KN95 face mask certification are almost the same as the requirements for US N95 FFP masks, which is why KN95 and N95 face masks provide same levels of protection to their users[93].

\subsubsection{FFP3}

FFP3 masks (Figure 5g) are the most protective of the FFP class masks[90]. Although in many countries such as the US, FFP2 masks are accepted in the stoppage of air transmission of infectious diseases, FFP3 masks are the only FFP masks accepted for protection against infectious aerosols in the UK[90]. This kind of FFP mask offers a filtration of at least $99 \%$ of particles, and they have the smallest inward leakage, $<2 \%[88]$. FFP3 respirators are recommended to be replaced after each use, if respiring becomes laborious, if the mask looks defective, or if it becomes contaminated with respiratory excretions or different body fluids[90].

\section{Antimicrobial face masks}

Face masks possess the capacity of restricting pathogens propagation and can prevent them reaching the respiratory system through the nose or mouth[94,95]. Most commercial face masks are currently manufactured with materials that are not endowed with antimicrobial properties, and thus do not reduce the risks of getting infected through bacterial or viral contact, or aerosol transmission. In this regard, many researchers have worked on the development of advanced face masks or smart masks capable of inactivating virus and bacteria. Thus, in 2007, Biedermann patented a face mask with a filter of non-woven polypropylene or polyester fabric, which involves an acidic polymer (Carbopol or Gantres type) coating the fibers that confer the mask an antiviral activity with up to $99.9 \%$ reduction in influenza A (H5N1) virus titer after 1 min incubation [96]. The major benefit of this invention is that its antiviral ability can be such that an oral and/or nasal filter can be manufactured in a lightweight way[97]. Moreover, filter materials of the device can be effective against pathogens or viruses such as Influenza A virus, SARS, RSV, bird flu, or mutated serotypes of these[97]. 
In 2011, a different study presented a replacement of the cellulosic filter layer of commercial face masks with a modified filter by poly(ethylenimine) that conferred antimicrobial properties to it[98]. Filters including this treatment showed a $5 \log _{10}$ reduction for T4D bacteriophage virus of Escherichia coli after 1 hour of contact time. Moreover, high antiviral activity against H5N2 was also described[98]. In 2012, Davison designed a new line of face masks (BioFriend ${ }^{\mathrm{TM}}$ BioMask $^{\mathrm{TM}}$ ) that was demonstrated to quickly inactivate many pathogen viruses, bacteria, or fungi. These face masks are composed of four layers: the outer one of spunbonded polypropylene, the second sheet of cellulose/polyester, the third cover of meltblown polypropylene, and the inner one made of spunbonded polypropylene. The first and second layers were treated with two different antimicrobial compounds not detailed in this work, but face masks showed more than 99.4\% reduction for virus tested and more than $88 \%$ reduction for bacteria[99].

In 2017, Hyo-Jick Choi's group discovered a new coating method for face masks filters using simple salt $(\mathrm{NaCl})$ that showed high efficiency to deactivate viruses like influenza $[100,101]$. They reported that this destruction ability is due to the natural recrystallization of salt on these surfaces[100,101]. In this regard, much progress has been achieved on the development of antimicrobial face masks capable of inactivating viruses such as SARSCoV-2 in the current COVID-19 pandemic, and even multidrug-resistant bacteria, which are reviewed in Table 3. 
Table 3. Antimicrobial face masks.

\begin{tabular}{|c|c|c|c|c|c|c|c|c|c|}
\hline Material & $\begin{array}{c}\text { Antimicrobial } \\
\text { agent }\end{array}$ & $\begin{array}{l}\text { Antiviral } \\
\text { activity }\end{array}$ & $\begin{array}{c}\text { Antibacterial } \\
\text { activity }\end{array}$ & Pore size & $\begin{array}{l}\text { Cytotoxicity } \\
\text { (cell line) }\end{array}$ & Breathability & $\begin{array}{l}\text { Bacterial } \\
\text { filtration }\end{array}$ & Year & Ref. \\
\hline $\begin{array}{l}\text { Non-woven } \\
\text { polypropylene or } \\
\text { polyester }\end{array}$ & $\begin{array}{l}\text { Acidic polymer of the } \\
\text { Carbopol or Gantres } \\
\text { type }\end{array}$ & $\begin{array}{l}\text { Yes (against Influenza } \\
\text { A virus, SARS, RSV, } \\
\text { or bird flu) }\end{array}$ & No data available & $\begin{array}{l}\text { No data } \\
\text { available }\end{array}$ & $\begin{array}{l}\text { No data } \\
\text { available }\end{array}$ & $\begin{array}{l}\text { Passed for NIOSH } \\
\text { N95 requirements }\end{array}$ & $\begin{array}{l}\text { Passed for } \\
\text { NIOSH N95 } \\
\text { requirements }\end{array}$ & 2007 & [96] \\
\hline $\begin{array}{l}\text { Polypropylene and } \\
\text { polyester }\end{array}$ & Copper oxide & $\begin{array}{l}\text { Yes (against Human } \\
\text { Influenza A virus and } \\
\text { avian influenza virus) }\end{array}$ & No data available & $\begin{array}{l}\text { No data } \\
\text { available }\end{array}$ & $\begin{array}{l}\text { No data } \\
\text { available }\end{array}$ & $\begin{array}{l}\text { Passed for NIOSH } \\
\text { N95 requirements }\end{array}$ & $\begin{array}{l}\text { Passed for } \\
\text { NIOSH N95 } \\
\text { requirements }\end{array}$ & 2010 & {$[97]$} \\
\hline Cellulose & Poly(ethylenimine) & $\begin{array}{l}\text { Yes (against T4D } \\
\text { bacteriophage virus } \\
\text { and } \mathrm{H} 5 \mathrm{~N} 2 \text { ) }\end{array}$ & No data available & $1-100 \mu \mathrm{m}$ & $\begin{array}{c}\text { No data } \\
\text { available }\end{array}$ & No data available & No data available & 2011 & {$[89]$} \\
\hline $\begin{array}{c}\text { Polyolefin fibers, } \\
\text { polypropylene, } \\
\text { polyethylene, and } \\
\text { poly 1-butene } \\
\text { fibers } \\
\end{array}$ & Silver ions & $\begin{array}{c}\text { Yes (against Influenza } \\
\text { A virus) }\end{array}$ & $\begin{array}{l}\text { Yes (bacteria not } \\
\text { mentioned) }\end{array}$ & $60-100 \mu \mathrm{m}$ & $\begin{array}{l}\text { No data } \\
\text { available }\end{array}$ & Passed & $\begin{array}{c}\text { Passed in } \\
\text { accordance with } \\
\text { ASTM F2101-07 } \\
(\geq 95 \%)\end{array}$ & 2012 & {$[100]$} \\
\hline $\begin{array}{l}\text { Polypropylene, } \\
\text { cellulose, polyester }\end{array}$ & Not data available & $\begin{array}{l}\text { Yes (against influenza } \\
\text { A and B viruses, } \\
\text { paramyxovirus, SARS- } \\
\text { CoV and herpes } \\
\text { simplex virus) } \\
\end{array}$ & $\begin{array}{c}\text { Yes (against } \\
\text { MRSA, M. terrae, } \\
\text { S. pneumoniae, } \\
\text { and H. influenzae) }\end{array}$ & $\begin{array}{l}\text { No data } \\
\text { available }\end{array}$ & $\begin{array}{l}\text { No data } \\
\text { available }\end{array}$ & $\begin{array}{c}\text { Passed for EN } \\
\text { 14683:2005 } \\
\text { requirements }\end{array}$ & $99.9 \%$ & 2012 & {$[90]$} \\
\hline Polypropylene & $\mathrm{NaCl}$ & Yes (influenza viruses) & No data available & $\begin{array}{l}\text { No data } \\
\text { available }\end{array}$ & $\begin{array}{l}\text { No data } \\
\text { available }\end{array}$ & No data available & $\sim 85 \%$ & 2017 & $\begin{array}{l}{[91],} \\
{[92]}\end{array}$ \\
\hline $\begin{array}{l}\text { Cotton and non- } \\
\text { woven } \\
\text { polyurethane } \\
\text { material } \\
\end{array}$ & $\begin{array}{l}\text { Graphene nanoplatelets } \\
\text { or Graphene oxide }\end{array}$ & $\begin{array}{l}\text { Yes (against SARS- } \\
\text { CoV-2) }\end{array}$ & $\begin{array}{l}\text { Yes (against } \\
\text { E.coli) }\end{array}$ & $\begin{array}{l}\text { No data } \\
\text { available }\end{array}$ & $\begin{array}{l}\text { Yes (VERO cells } \\
\text { and A549 } \\
\text { pulmonary tumor } \\
\text { cells) } \\
\end{array}$ & No data available & No data available & 2020 & [105] \\
\hline $\begin{array}{l}\text { Low-cost } \\
\text { electrothermal } \\
\text { mask }\end{array}$ & Graphene layer & No data available & $\begin{array}{l}\text { Yes (against } \\
\text { E.coli) }\end{array}$ & $\begin{array}{l}\text { No data } \\
\text { available }\end{array}$ & $\begin{array}{l}\text { No data } \\
\text { available }\end{array}$ & No data available & No data available & 2020 & [102] \\
\hline Polypropylene & Benzalkonium chloride & $\begin{array}{l}\text { Yes (against SARS- } \\
\text { CoV-2 and phi 6) }\end{array}$ & $\begin{array}{l}\text { Yes (against } \\
\text { MRSA and } \\
\text { MRSE) }\end{array}$ & $10-50 \mu \mathrm{m}$ & $\begin{array}{l}\text { No data } \\
\text { available }\end{array}$ & No data available & Not tested & 2021 & {$[93]$} \\
\hline
\end{tabular}




\begin{tabular}{|c|c|c|c|c|c|c|c|c|c|}
\hline Polypropylene & $\begin{array}{l}\text { Shellac/copper } \\
\text { nanoparticles }\end{array}$ & $\begin{array}{l}\text { Yes (viruses not } \\
\text { mentioned) }\end{array}$ & $\begin{array}{l}\text { Yes (against } \\
\text { E.coli) }\end{array}$ & $\begin{array}{l}\text { No data } \\
\text { available }\end{array}$ & $\begin{array}{l}\text { No data } \\
\text { available }\end{array}$ & Passed & $\begin{array}{c}36 \% \text { for } \sim 300 \mathrm{~nm} \\
\text { particles and } \\
81 \% \text { for } \sim 1 \mu \mathrm{m} \\
\text { particles } \\
\end{array}$ & 2021 & [111] \\
\hline No data available & $\begin{array}{l}\mathrm{EVA}-\mathrm{SiO}_{2}-\mathrm{Ag} \\
\text { composite }\end{array}$ & $\begin{array}{l}\text { Yes (against SARS- } \\
\text { CoV-2) }\end{array}$ & $\begin{array}{l}\text { Yes (against E.coli } \\
\text { and } \\
\text { Staphylococcus } \\
\text { aureus) }\end{array}$ & $\begin{array}{l}\text { No data } \\
\text { available }\end{array}$ & $\begin{array}{l}\text { No data } \\
\text { available }\end{array}$ & No data available & No data available & 2021 & [103] \\
\hline Synthetic polymers & $\begin{array}{l}\text { Glycyrrhetinic acid and } \\
\text { glycyrrhizin }\end{array}$ & $\begin{array}{c}\text { Yes (against Hepatitis } \\
\text { C virus, SARS, RSV, } \\
\text { HIV) }\end{array}$ & No data available & $\begin{array}{l}\text { No data } \\
\text { available }\end{array}$ & $\begin{array}{l}\text { No data } \\
\text { available }\end{array}$ & $\begin{array}{l}\text { Ensures good } \\
\text { breathability }\end{array}$ & No data available & 2021 & [116] \\
\hline Polypropylene & Copper nanoparticles & $\begin{array}{l}\text { Yes (against SARS- } \\
\text { CoV-2) }\end{array}$ & No data available & $\begin{array}{l}\text { No data } \\
\text { available }\end{array}$ & $\begin{array}{l}\text { No data } \\
\text { available }\end{array}$ & No data available & $\begin{array}{l}>91 \% . \text { Passed for } \\
\text { EN143 and } \\
\text { EN149 standards }\end{array}$ & 2021 & [99] \\
\hline No data available & Polyphenols & $\begin{array}{l}\text { Yes (against HAdV5 } \\
\text { and HCoV229E) }\end{array}$ & $\begin{array}{l}\text { Yes (against } K . \\
\text { pneumoniae) }\end{array}$ & $\begin{array}{c}\text { No data } \\
\text { available }\end{array}$ & $\begin{array}{l}\text { Yes (cell line not } \\
\text { mentioned) }\end{array}$ & No data available & No data available & 2021 & [117] \\
\hline $\begin{array}{l}\mathrm{TiO}_{2} \text { nanotubes as } \\
\text { fillers into } \\
\text { chitosan/poly(vinyl } \\
\text { alcohol) polymeric } \\
\text { electrospun } \\
\text { nanofibers } \\
\end{array}$ & $\begin{array}{l}\mathrm{TiO}_{2} / \text { chitosan/poly(vinyl } \\
\text { alcohol) }\end{array}$ & No data available & $\begin{array}{l}\text { Yes (against } S \text {. } \\
\quad \text { aureus) }\end{array}$ & $\begin{array}{c}711.2 \pm 190.9 \\
\mathrm{~nm} \text { for } \\
\mathrm{TiO}_{2} / \mathrm{Cs} / \mathrm{PVA} \\
\text { layer }\end{array}$ & $\begin{array}{l}\text { No data } \\
\text { available }\end{array}$ & $\begin{array}{l}\text { Breathability level } \\
\text { very reasonable }\end{array}$ & $>93 \%$ & 2021 & {$[46]$} \\
\hline $\begin{array}{c}\text { Two biodegradable } \\
\text { microfiber and } \\
\text { nanofiber mats } \\
\text { integrated into a } \\
\text { Janus membrane } \\
\text { filter } \\
\end{array}$ & $\begin{array}{l}\text { Coating of cationically } \\
\text { charged chitosan } \\
\text { nanowhiskers }\end{array}$ & No data available & No data available & $\begin{array}{l}\text { Average pore } \\
\text { sizes of } 0.51- \\
13.1 \mu \mathrm{m}\end{array}$ & $\begin{array}{l}\text { No data } \\
\text { available }\end{array}$ & $\begin{array}{c}\text { Comfortable } \\
\text { breathability level } \\
\text { (low pressure } \\
\text { differential of } 59 \\
\mathrm{~Pa} \text { ) }\end{array}$ & $\begin{array}{l}98.3 \% \text { of } 2.5 \mu \mathrm{m} \\
\mathrm{PM}(\mathrm{N} 95 \text { level). }\end{array}$ & 2021 & [103] \\
\hline $\begin{array}{l}\text { Superhydrophobic, } \\
\text { photo-sterilize, and } \\
\text { reusable masks }\end{array}$ & $\begin{array}{l}\text { High-density edges of } \\
\text { standing structured } \\
\text { graphene nanosheets }\end{array}$ & No data available & No data available & $\begin{array}{l}\text { No data } \\
\text { available }\end{array}$ & $\begin{array}{l}\text { No data } \\
\text { available }\end{array}$ & No data available & $100 \%$ & 2021 & [104] \\
\hline $\begin{array}{c}\text { Superhydrophobic, } \\
\text { photo-sterilize, and } \\
\text { reusable surgical } \\
\text { masks }\end{array}$ & Few-layer graphene & No data available & No data available & $\begin{array}{l}\text { No data } \\
\text { available }\end{array}$ & $\begin{array}{l}\text { No data } \\
\text { available }\end{array}$ & No data available & No data available & 2021 & {$[105]$} \\
\hline
\end{tabular}


Thus, new generation antimicrobial face masks have been developed using different antimicrobial materials such as benzalkonium chloride[106], metal and metal oxides[107-116], carbon-derived materials[117-123], photoactive materials[124], natural compounds[125-130], and biodegradable compounds[54,103].

\subsection{Benzalkonium chloride}

Very recently, the first face mask filter capable of neutralizing SARS-CoV-2 in one minute and multidrug-resistant bacteria such as methicillin-resistant Staphylococcus aureus and Staphylococcus epidermidis has been developed as a new promising tool to strop the increasing COVID-19 spread[106]. Martí et al. discovered that treating nonwoven spunlace fabric filters by the dip-coating method[131] with quaternary ammonium, benzalkonium chloride (BAK), is an efficient and economic tool to face the current SARS-CoV-2 pandemic, since this treatment provides filters with superior antiviral properties due to the ability to inhibit SARS-CoV-2 after 1 minute of contact (see Figure 6a)[106]. 
(a)

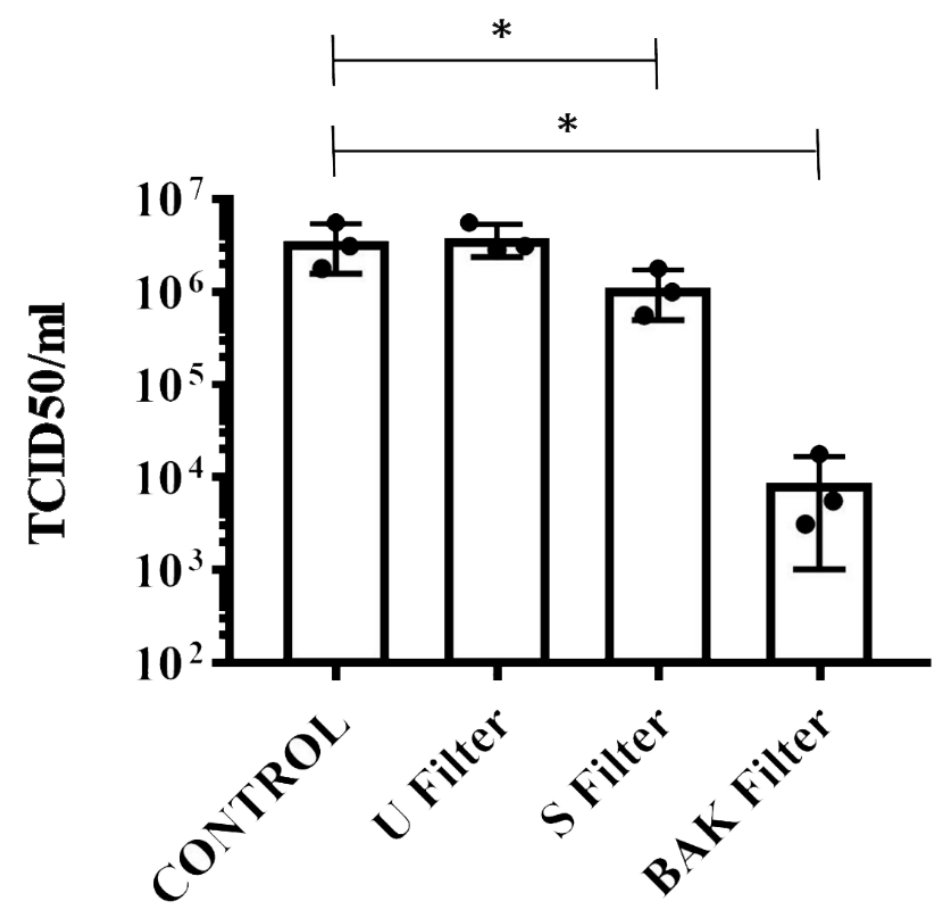

(b)

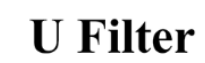

S Filter

BAK Filter

MRSE

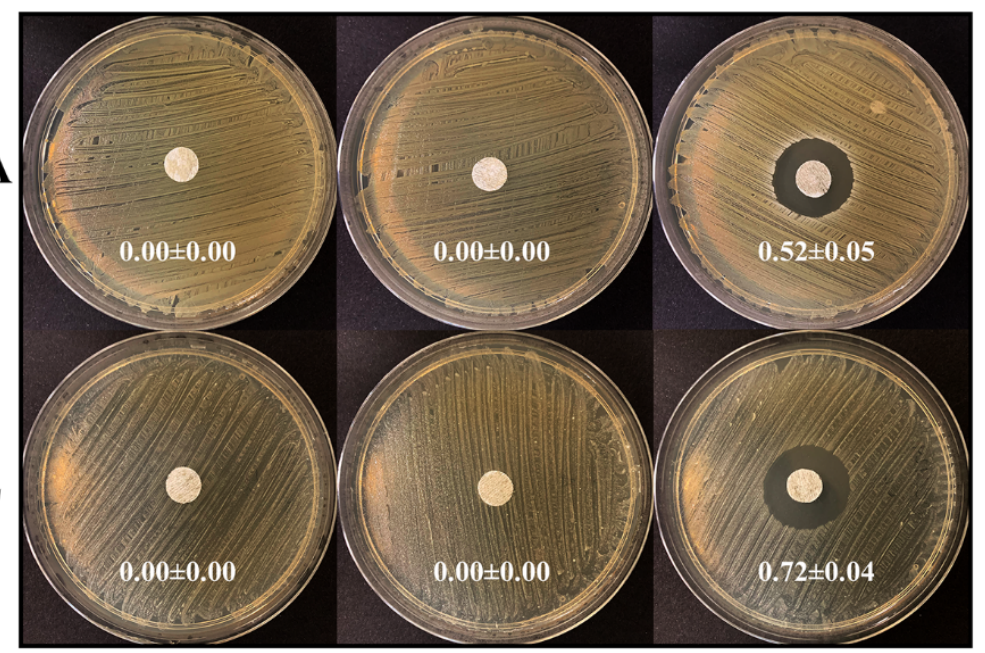

Figure 6. Decrease of infectivity of SARS-CoV-2 after 1 minute of contact using Vero cells (a) Not-treated filter (U filter), filter with an ethanol 70\% treatment (S filter), filter with the BAK covering (BAK filter) and control via the TCID50/mL method (from Martí et al.[106]). Antibacterial tests against MRSA and MRSE (b) Not-treated filter (U filter), filter with an ethanol $70 \%$ treatment (S filter) and filter with the BAK covering (BAK filter) after 24 hours of culture at $37^{\circ} \mathrm{C}$ (from Martí et al.[106]).

Moreover, BAK treatment supplies filters not only with antiviral properties but also with antibacterial activity [106]. This group has demonstrated that their novel filters are capable of inactivating multidrug-resistant bacteria such as methicillin-resistant Staphylococcus aureus and Staphylococcus epidermidis (see Figure 6b)[106]. These bacteria represent a rapidly growing danger because, according to the $\mathrm{WHO}$, antibiotic 
resistance will become a major cause of death by the year 2050, even surpassing other considerable illnesses like cancer[132].

\subsection{Metal and metal oxides}

During the SARS-CoV outbreak in 2002, infections through contaminated PPEs surfaces were around $20 \%$ of total infections among healthcare workers[133]. For this reason, researchers started exploring options that could reduce the spread of infections by coating PPEs with antimicrobial substances[107]. With this in mind, scientists realized that metalbased nanoparticles possess antibacterial and antimicrobial capacities[107,108]. Thus, research led to discoveries of metals such as silver, copper, or zinc with the ability to restrict virus spread by incorporating them in PPEs[107,108]. It was shown that copper and copper oxide have strong antiviral properties[109], even when facing SARS-CoV$2[134]$. It is also known that by making use of a non-woven fabric permeated with copper oxide particles, 99.9\% of Human Influenza A (H1N1) and Avian Influenza Virus (H9N2) virions were non-infectious after 30 minutes of contact[110]. That was the reason why, in a different study carried out by Borkow et al.[110], copper oxide particles were integrated in FFP1 medical respiratory masks (see Figure 7).

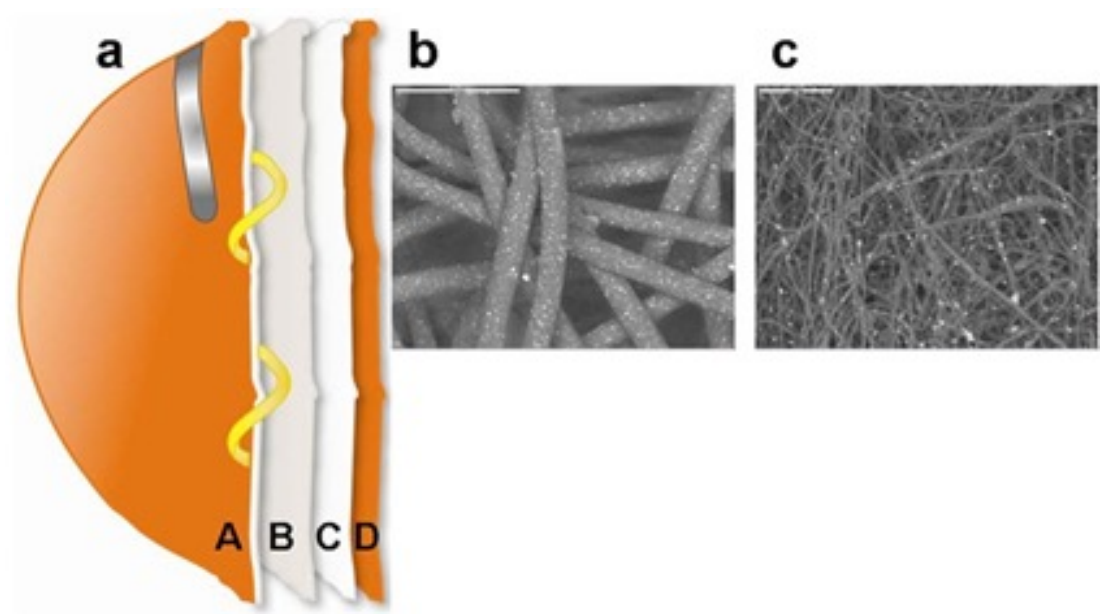

Figure 7. Antimicrobial face mask with a copper oxide coating. a) This mask is made up of 2 external (A and D) spunbond polypropylene layers which include $2.2 \%$ copper oxide particles (weight/weight), one inner (B) meltblown polypropylene layer comprising $2 \%$ copper oxide particles $(\mathrm{w} / \mathrm{w})$, and a polyester one $(\mathrm{C})$ with no copper oxide particles. b) Outer layer A image with scanning electronic microscope. c) Internal layer B picture with scanning electronic microscope. (Adapted from Borkow et al. [110])

This group has demonstrated that copper oxide particles do not modify a mask's filtration properties but do kill the remaining virions in the mask[110]. This is highly important due 
to the infectious capacity of the residual virions in the mask, which is capable of being a wellspring of viral transference to the mask bearer and to others, as remarked by the WHO[111]. Jung et al. also reported a copper-coated polypropylene filter for face masks with antiviral activity against SARS-CoV-2[112]. They deposited the copper thin films on the spunbond fabric by a direct current magnetron sputtering system and concluded that the filtration efficiency for these masks was higher than $91 \%$ and SARS-CoV-2 was inactivated after 1 hour of contact[112].

Shibata et al. patented a face mask whose intermediate layer included polyolefin fibers containing an inorganic antimicrobial agent[113]. These authors propose the use of inorganic antimicrobial materials in which metals possess an antibacterial and antiviral effect, such as silver, copper, zinc, or titanium oxide [113]. The suggestion of applying these compounds on inorganic carriers that do not exhibit any effect of deteriorating fiber sheets was made by Shibata et al.[113]. Zeolite and zirconium phosphate are recommended as the most suitable[113]. This face mask is manufactured in order to avoid secondary infections with pathogens because, when breathing, airborne droplets which contain bacteria or viruses flow directly to the fiber sheet containing the antimicrobial agent, since the first layer is made of hydrophobic fibers[113].

It is highly important to remark that important antibacterial activity was described for metal oxide nanoparticles and their composites[114,115]. This aptitude was reported as the capacity to produce reactive oxygen species (ROS) causing subsequent oxidative stress in cells[114,115]. In this context, Assis et al. presented a new composite with high antiviral activity, composed by a polymer matrix constructed from $\mathrm{SiO}_{2}$ anchored with silver nanoparticles [116]. Results obtained from this group's experiments showed signs of high antibacterial activity against Escherichia coli (E. coli) and Staphylococcus aureus (S. aureus) and antiviral (SARS-CoV-2) activity [116]. As this advanced $\mathrm{SiO}_{2}-\mathrm{Ag}$ composite shows highly remarkable advantages for its use as a material biocide, and dismissal of SARS-CoV-2, Assis' group propose the use this material as a component for manufacturing reusable face masks[116] (see Figure 8). 


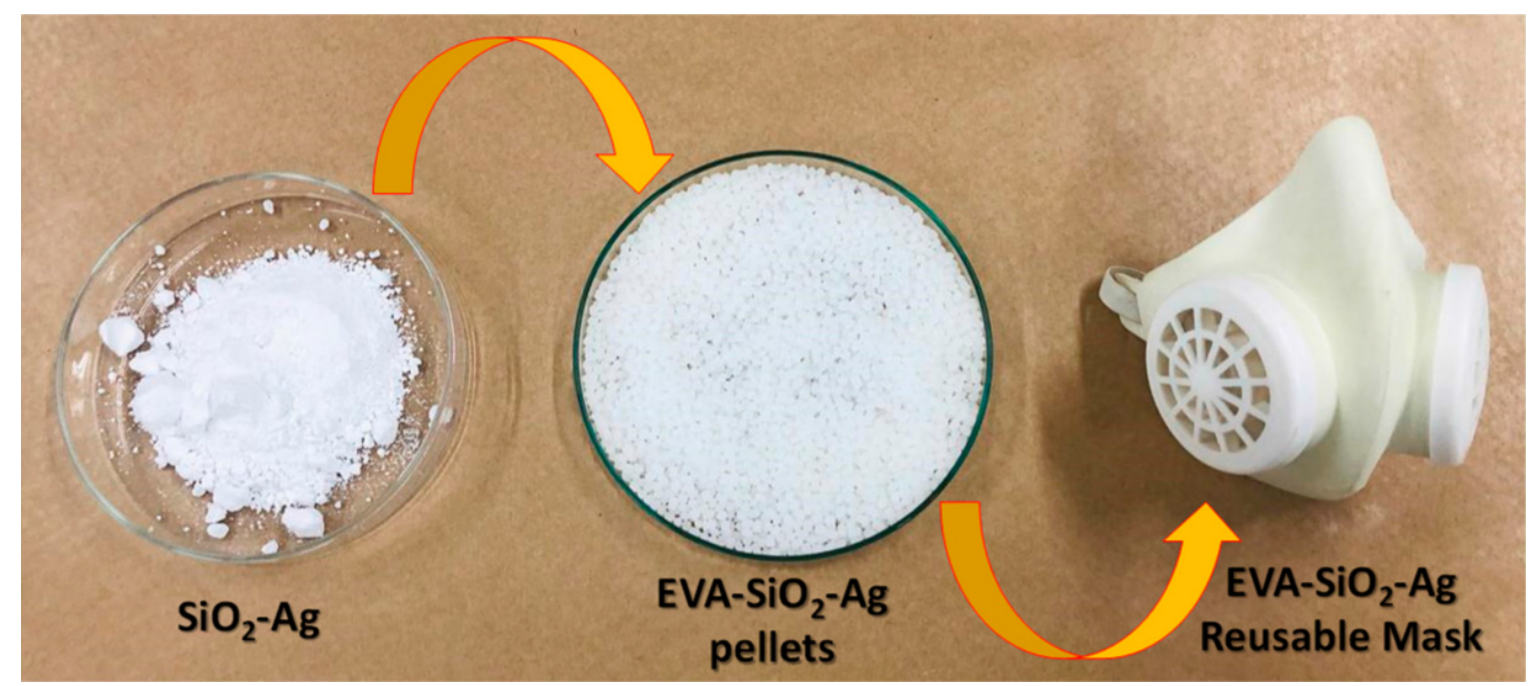

Figure 8. Reusable mask manufactured using the EVA-SiO2-Ag composite (Assis et al.[116]).

\subsection{Carbon-derived and photoactive materials}

Carbon-derived nanomaterials such as graphene oxide (GO) sheets or graphene oxide sheets with silver jots have been demonstrated to possess antiviral properties[135]. GO sheets with silver particles are known to have antiviral properties against enveloped and non-enveloped viruses, while GO sheets on their own were proved to prevent infection of an enveloped virus[135] such as SARS-CoV-2[136]. Thus, De Maio et al. described graphene-based face mask capable to inhibit the infectivity of SARS-CoV-2[118]. In addition to its antiviral properties, bacteria that rub against graphene surfaces are also known to lose integrity[119,120]. Graphene has been described to interact with viruses by hydrogen bonding, electrostatic interactions, and redox reactions[121]. Moreover, numerous graphene-derived substances possess the capacity to adsorb charged lipids and dismantle membranes like the ones belonging to SARS-CoV-2 [122,123,135]. De Maio and colleagues verified that water-soluble GO inter-reacts with SARS-CoV-2 viral particles and decreases its infectivity in the in vitro model of Vero cells[118]. According to these results, this group decided to design an effective surgical face mask where graphene and graphene oxide was integrated in these materials[118]. Kumar et al.[124] reported a novel antimicrobial face mask (see Figure 9). 


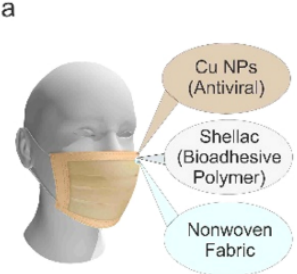
Photoactive Antivira Mask (PAM)

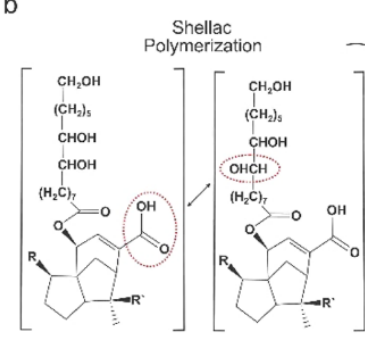

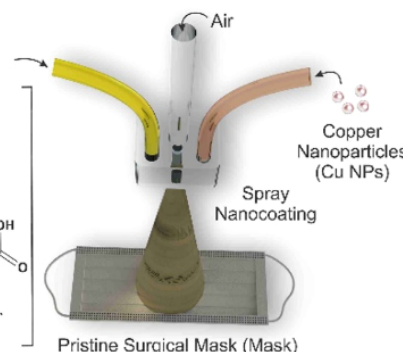

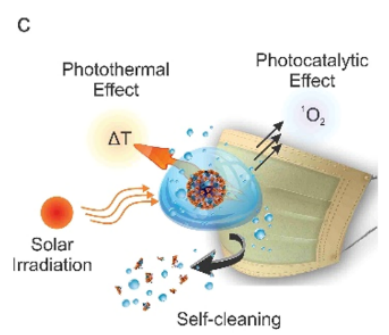

d

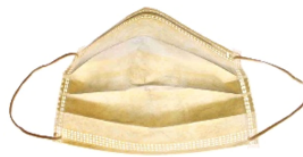

PAM
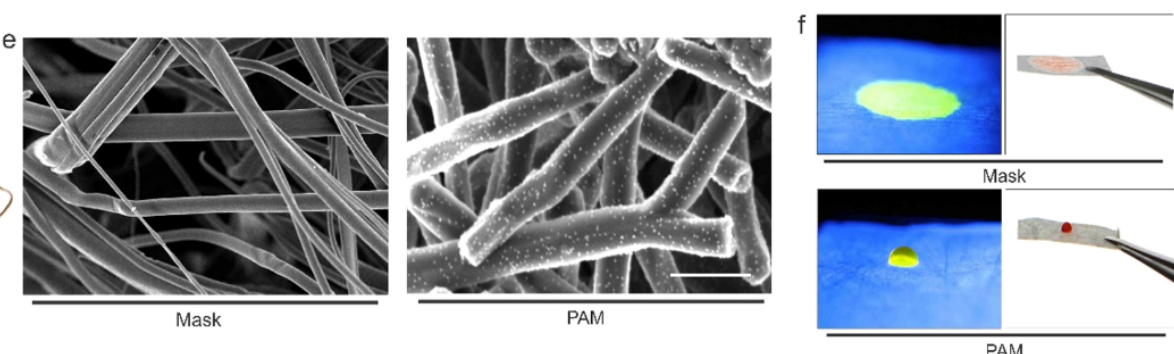

Figure 9. Surface modification of pristine surgical masks: (a) Representative image of the individual components of the photoactive antiviral mask (PAM) composed of a commercial surgical mask coated with the nanocomposite; (b) Scheme of the setup of the spray-based microfluidic device designed to mix the copper nanoparticles (CuNPs) dispersion and shellac at the junction for the controlled deposition of the nanocomposite on nonwoven fibers of the pristine surgical mask.; (c) Scheme of the inactivation of viral particles in respiratory droplets via photothermal, photocatalytic, and hydrophobic self-cleaning after solar irradiation. (d) Macroscopic image of the photoactive antiviral PAM mask.; (e) Scanning electron micrographs of the commercial surgical masks with propylene nonwoven fibers (left) and the antiviral masks with shellac-CuNPs nanocomposite-coated nonwoven fibers (right). (White scale bar at $10 \mu \mathrm{m}$ ); (f) Macroscopic images of a colored water droplet of $30 \mu \mathrm{L}$ placed on the pristine mask (top) and PAM (bottom) after 1 h. (Kumar et al. [124]).

This mask included a hydrophobic supplement with photoactive nanocomposite modification by covering the polypropylene non-woven fabrics of profitable face masks, which is able to fracture the plasma membrane of virus-like particles under daylight[124]. This nanocoating for face masks consists of a hybrid of shellac/copper nanoparticles, where shellac is a natural biopolymer including a combination of polyhydroxy, polycarboxylic esters, lactones, and anhydrides, and its use is widely extended as a bioadhesive or biocompatible coating material [137-139]. Moreover, it includes copper nanoparticles, as they are demonstrated to possess a quick and elevated microbicidal activity against pathogens, and also encourage photocatalysts[140-142]. The effect of this new antiviral and antibacterial lies in the capacity of shellac to absorb light in UVvisible regions[124]. This aptitude makes the mask able to elevate its surface temperature above $70^{\circ} \mathrm{C}$ within 5 minutes when exposed to sunlight, a temperature which is adequate for SARS-CoV-2 inhibition[124]. The antiviral activity of carbon-based materials has also been attributed to a photothermal antiviral mechanism and/or reactive oxygen species generation[143]. A method for functionalizing commercially available surgical masks by 
a dual-mode laser-induced forward transfer method to deposit few-layer graphene onto nonwoven fabrics with superhydrophobicity, and outstanding self-cleaning and photothermal properties has been reported[105] (Figure 10).
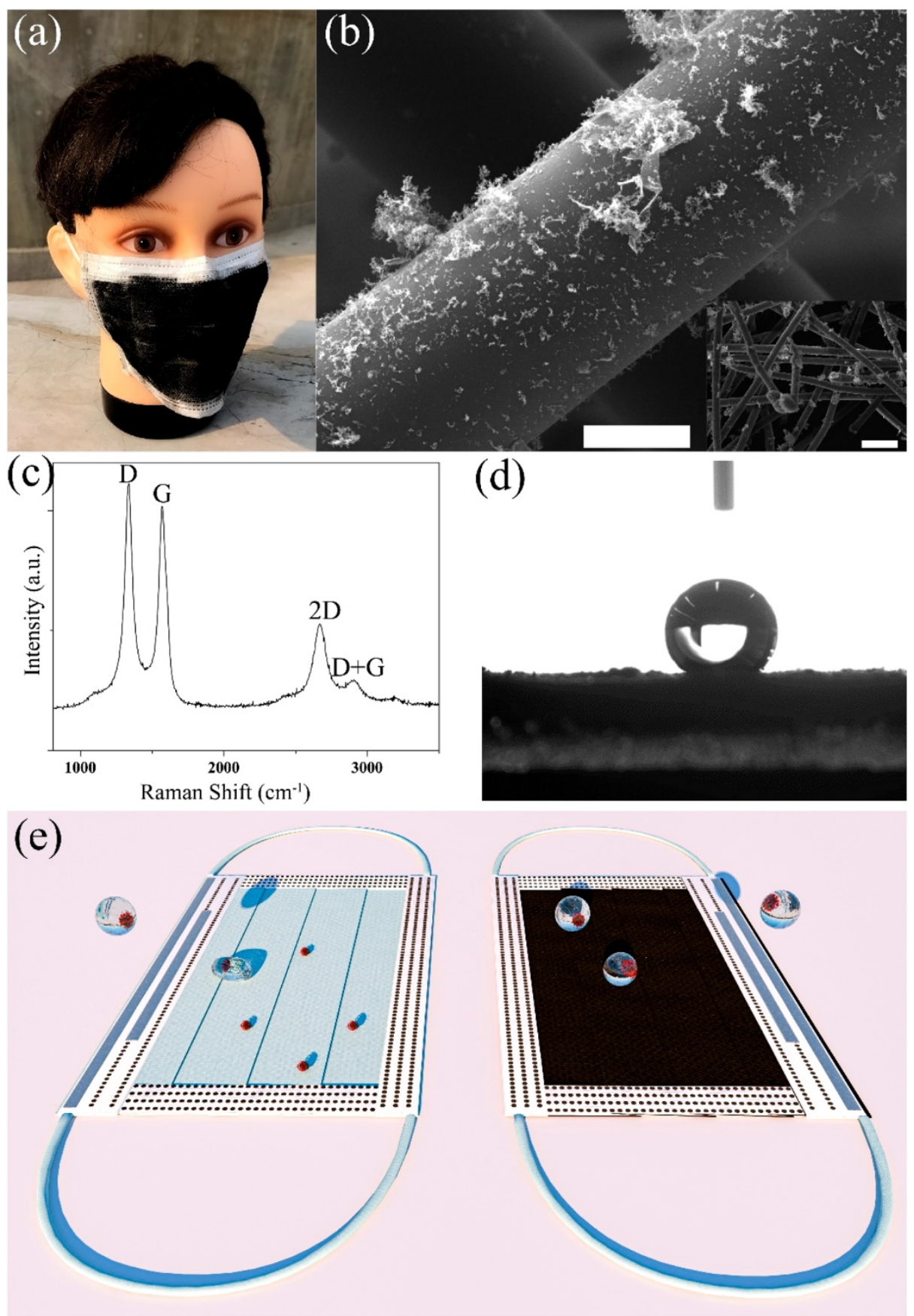

Figure 10. Representative image of the laser-fabricated graphene mask. (a); Scanning electron microscopy of the graphene-coated nonwoven fiber of the graphene mask at two magnifications: image with white scale bar at $10 \mu \mathrm{m}$ and zoom-out image with white scale bar at $100 \mu \mathrm{m}$. (b); Raman spectroscopy of the graphene-coated mask. (c); Contact angle on the graphene-coated mask measured using liquid water. (d); Representative images of the self-cleaning performance of the black graphene coated mask (right), compared to the uncoated blue mask(left) (e) (Zhong et al. [105]). 
These masks can be reusable after sterilization under sunlight illumination because they can rapidly reach over $80^{\circ} \mathrm{C}$. A novel low-cost electrothermal mask with excellent selfsterilization performance was fabricated with a cloth tape with a graphene layer [102]. The operation under a low voltage of $3 \mathrm{~V}$, the mask can quickly generate large amounts of heat to achieve a high temperature above $80{ }^{\circ} \mathrm{C}$, which could kill E. coli. Another superhydrophobic, photo-sterilize, and reusable mask based on graphene nanosheetembedded carbon film has been recently developed with high-density edges of standing structured graphene nanosheets[104]. This carbon-based mask exhibited excellent $100 \%$ filtration efficiency, hydrophobic ability $\left(157.9^{\circ}\right.$ of water contact angle $)$ and fast photosterilize performance (up to $110^{\circ} \mathrm{C}$ ) under the solar irradiation. Most face masks are made of hydrophobic materials such as polypropylene (PP) in order to reduce adhesion (see Table 1 and 2). However, face masks treated with a superhydrophobic coating may not be the best selection because it can give rise to a number of smaller daughter droplets that can linger in air for longer times and can increase the chance of microbial transmission[74].

\subsection{Natural compounds}

Natural compounds such as licorice root extract was employed by Chowdhury and colleagues to design and manufacture a new antiviral face mask with antimicrobial features conferred by glycyrrhetinic acid and glycyrrhizin[129]. It was described before that glycyrrhizin was the greatest effective substance of licorice root in inactivating the SARS related virus[127]. Glycyrrhizinic acid is a triterpenoid saponin that is also set apart from licorice root and has been proven to be effective against human viruses such as Hepatitis C Virus[126]. Moreover, researchers described that this compound could also deactivate SARS-CoV-2 and restrain its replication[128]. According to all these discoveries and the necessity of prevention in the COVID-19 issue, Chowdhury's group decided to create this novel face mask (see Figure 11) to avoid the spread of the virus[129]. 


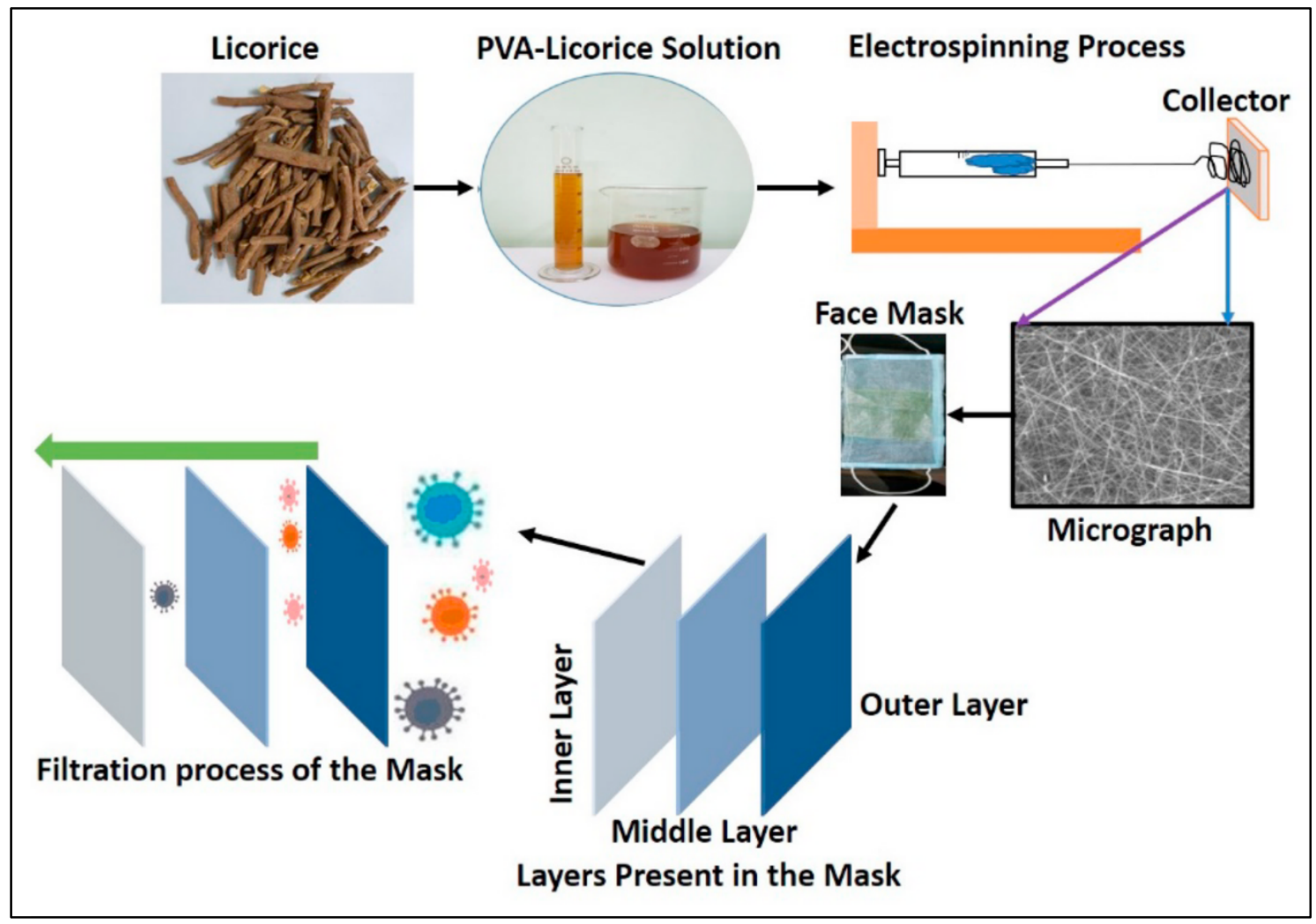

Figure 11. Diagram of licorice-treated face mask production. (Chowdhury et al.[129])

Passaglia's group reported an innovative manner to improve the blocking effect of surgical masks[130]. Their discovery consisted of a combination of bioactive composites, principally polyphenols, obtained from agronomical origins, which are accumulated in the external surface of the surgical mask and provide it with virucidal properties[130]. This group hypothesizes that the cooperation of polyphenols with the beta structures of protein S of SARS-CoV-2 could lead to structural modifications that could forestall the offensive of the virus into the host cell[130]. Furthermore, many applications of polyphenols for treating of materials to confer antiviral properties were described before [125]. For this reason, these authors thought that operation of these polyphenolic compounds on the outer layer of medical equipment, such as surgical masks, was expected to provide them with antimicrobial properties by inactivating virions and reducing the possibility of causing cross-contamination[130]. In addition, this group confirmed the antiviral function of these natural composites that can be used in order to enhance the barrier effect of surgical masks[130]. They demonstrated that human viruses such as human adenovirus HAdV5 or human coronavirus HCoV229E were sensitive to compounds with a valuable content of polyphenols, such as hydroalcoholic extracts of clove blossoms, olive leaves, or green tea[130] (see Table 4). 


\begin{tabular}{|c|c|c|c|c|}
\hline & $\begin{array}{c}\text { INITIAL VIRUS } \\
\text { TITER }\end{array}$ & $\begin{array}{c}\text { TITER AFTER } \\
\text { TEST (TCID50 } \pm \text { SD) }\end{array}$ & $\begin{array}{c}\text { LOG10 } \\
\text { REDUCTION }\end{array}$ & $\begin{array}{c}\text { PERCENTAGE } \\
\text { REDUCTION }\end{array}$ \\
\hline $\begin{array}{c}\text { Clove buds } \\
\text { extract HAdV5 }\end{array}$ & $5.40 \mathrm{E}+04 \pm 1.60 \mathrm{E}+04$ & $2.33 \mathrm{E}+03 \pm 2.10 \mathrm{E}+03$ & 1.36 & $95.60 \%$ \\
\hline $\begin{array}{c}\text { Clove buds } \\
\text { extract } \\
\text { HuCoV229E }\end{array}$ & $7.77 \mathrm{E}+03 \pm 6.61 \mathrm{E}+03$ & $5.27 \mathrm{E}+03 \pm 0.91 \mathrm{E}+03$ & 0.16 & $32.2 \%$ \\
\hline $\begin{array}{c}\text { Olive leaves } \\
\text { extract HAdV5 }\end{array}$ & $5.40 \mathrm{E}+04 \pm 1.60 \mathrm{E}+04$ & $4.58 \mathrm{E}+03 \pm 3.33 \mathrm{E}+03$ & 1.07 & $91.50 \%$ \\
\hline $\begin{array}{c}\text { Olive leaves } \\
\text { extract } \\
\text { HuCoV229E }\end{array}$ & $7.77 \mathrm{E}+03 \pm 6.61 \mathrm{E}+03$ & $8.43 \mathrm{E}+02 \pm 0$ & 0.96 & $89.15 \%$ \\
\hline
\end{tabular}

Table 4. Results of antiviral assays carried out on HAdV5 and HuCoV229E employing clove bud and olive leave extract. No time of contact is described. (Adapted from Passaglia et al.[130]).

Two biodegradable microfiber and nanofiber mats were integrated into a hierarchical multiscale hyperporous membrane (Janus membrane) coated by cationically charged chitosan nanowhiskers to produce a biodegradable, moisture-resistant, high breathability (low pressure differential of $59 \mathrm{~Pa}$ ), and high-performance fibrous mask filter that decomposes within 4 weeks in composting soil. Although the antimicrobial activity of chitosan is well-know[144,145], further research is necessary to test the antimicrobial properties of this mask filter[103].

\section{Future trends}

COVID-19 has affected the world severely, claiming many lives and has shown the importance of illness prevention. When SARS-CoV-2 emerged around the globe, none of the countries were prepared for facing such a tough virus. Preliminary inadequate research on the nature of the virus, its survival, and transmission rate from surfaces to humans caused the outbreak. Therefore, it is extremely important to respond quickly to actual pandemic, combine efforts to produce and transform knowledge into products as well as to streamline the use of these new tools and technologies for the prevention of future outbreaks and any global health emergencies. In addition, a lack of personal protective equipment (PPE) including gloves, safety glasses, respirators, bodysuits, or face masks was the major obstacle in fighting virus at the beginning of the COVID-19 pandemic. It is important to mention the initial discrepancies between governments in different countries and the WHO in terms of covering the mouth and nose with face masks for preventing the spread of COVID-19. At first, WHO recommended face mask use only in 
symptomatic patients or people taking care of them. Symptomatic and asymptomatic spread from one person to the other leads to the global spread, which needs to be diagnosed at an early stage without any invalid results. Discovery of viral transmission through asymptomatic carriers led governments and WHO to, at first, recommend wearing masks to general population and, finally, to become an obligation for all citizens. Many studies have drawn attention to the efficiency of wearing face masks to prevent the transmission of viruses such as influenza virus or even SARS-CoV-2 itself. It has become crucial to avoid the transmission of micro-and/ or macro-organisms responsible of potentially fatal diseases. Their prevention remains a prominent threat to the public health through precautions and keep premises hygienic using high-performance anti-viral materials to trap and eradicate SARS-CoV-2. Viruses are not the only microorganisms able to cause diseases on a global scale. Multidrug-resistant bacteria are emerging as a highly notable cause of death, and they are expected by WHO to exceed cancer as a cause of death by the year 2050. Researching this issue is another challenge for scientists in the coming years. A possible discovery of treatments against this kind of resistant bacteria would result in multiple benefits, especially for healthcare workers, protecting them against infections that may cause severe problems. In the current context, the prevention of the contamination and transmission of pathogens, including viruses, bacteria, and fungi, are a priority. In fact, many companies have already incorporated new technologies in the fabrication of face masks to provide extra protection to the population in the current COVID-19 pandemic. Finally, it is necessary to remark that face masks have come to serve a variety of situations in daily routines and have become an important partner in daily life for people around the world. Global use of face masks in the general population also brings out a new problem due to the large number of biological residues they cause. Antiviral and/or biodegradable face masks might assist in reducing these residues by eliminating potentially infectious viral particles that remain in masks, or even by decomposing themselves if made with biodegradable materials. The viral infection of the SARS-CoV-2 virus has attracted researchers to combine interdisciplinary areas. In this regard, materials science and nanotechnology have significantly contributed to the fight against virus outbreaks, by successfully synthesis of different types of materials with excellent antiviral properties[49,50]. However, further studies are warranted for the functionalization of these materials on communal objects (e.g., mask, door handles, elevator buttons, gas pumps, and railings) to reduce both disease transmission and fear of touching objects. 


\section{Conclusions}

The COVID-19 pandemic has triggered not only a global health problem but an economic issue too, leading countries worldwide to a huge economic crisis that has had societal and environmental impacts. It has aggravated the differences between social ranks and poverty in case of many families, causing an irreversible harm to society. It has been a critical situation for governments in terms of populations' lives. Strict measures for preventing SARS-CoV-2 spread had to be taken and led to very severe confinement all around the world. After confinement, severe measures to control COVID-19 spread were taken across the world to protect citizens' lives. These measures included the advice to wear face masks in public and poorly ventilated places, which seems to be the most effective strategy against the spread of the virus SARS-CoV-2 and many other bacterial pathogens, including multidrug-resistant strains within the community. However, wearing face masks also causes a big environmental problem. Single-use face masks generate a huge amount of urban and biological residues, which represent a big challenge for the population and environment in terms of treating these kinds of remainders. Moreover, the possibility of cross-contamination exists while dealing with these items. Regarding this biological problem, researchers have made efforts to discover new compounds with antimicrobial activity and develop not only face masks but other PPEs as well. This is done to restrict SARS-CoV-2 spread in the general population, since the virus will become inactivated and lose its infectivity after coming in contact with antiviral materials. Additionally, antiviral face masks have a higher useful life because of their ability to kill viruses and bacteria. This would turn into a minor quantity of residues and could help solve the problem of waste generation.

Finally, it is important to mention that many biodegradable materials are currently being developed which could be integrated in PPE manufacturing procedures. In summary, antimicrobial face masks are important tools to prevent viral and multidrug-resistant bacterial infections. However, more effort must be conducted towards the development of antimicrobial biodegradable face masks capable of solving the increasing environmental problem produced with the massive utilization of single-use face masks by the general population. This progress has contributing significantly due to the development of new technologies, based on the synthesis of potent biocide materials, due to a substantial cumulative knowledge that was translated rapidly for various multi- 
tasking applications such as PPE such as gloves, face masks, clothing, etc. as well as disinfection of the surfaces/surroundings.

\section{Graphical abstract}

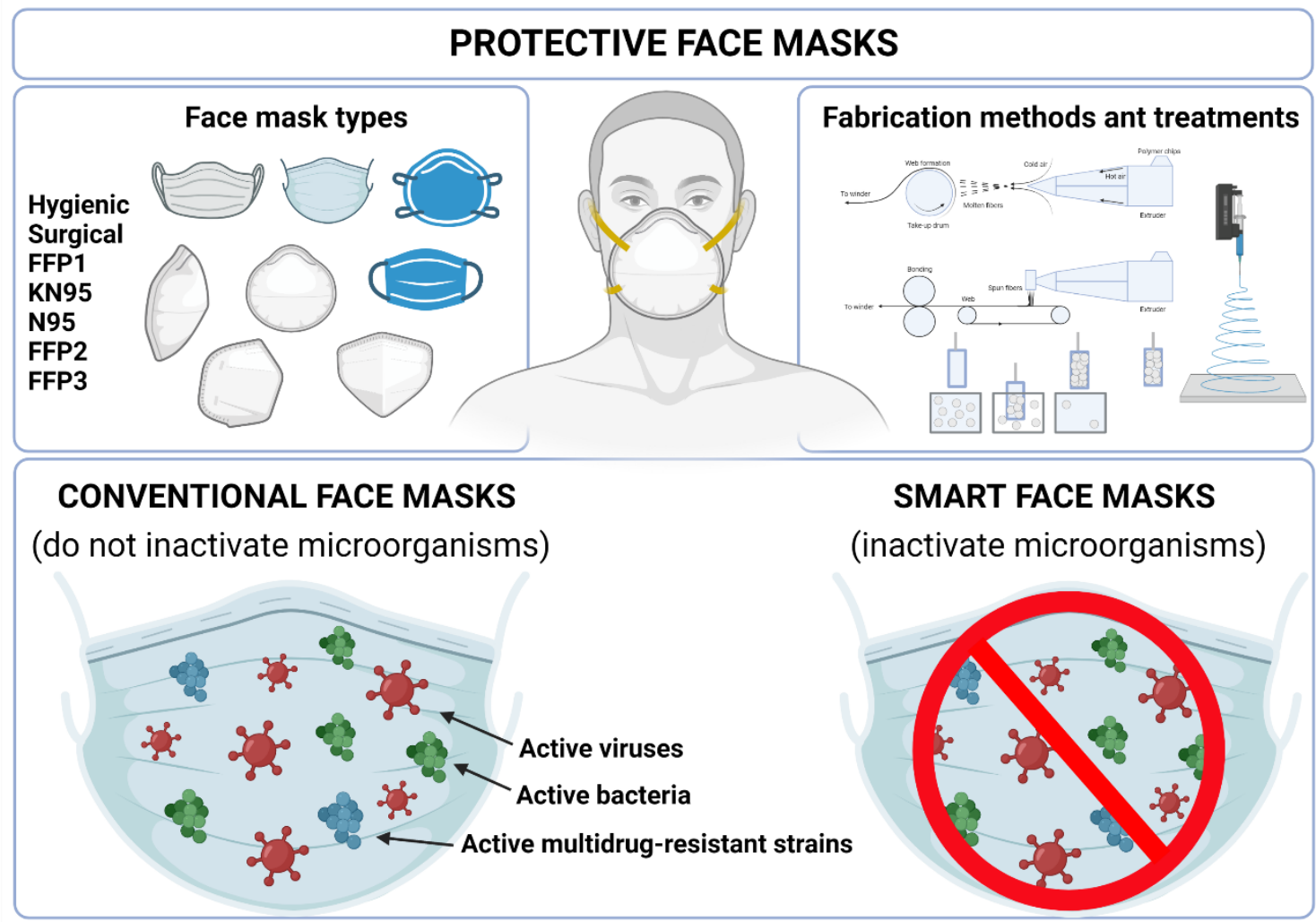

\section{References}

[1] N. Zhu, D. Zhang, W. Wang, X. Li, B. Yang, J. Song, X. Zhao, B. Huang, W. Shi, R. Lu, P. Niu, F. Zhan, X. Ma, D. Wang, W. Xu, G. Wu, G.F. Gao, W. Tan, A Novel Coronavirus from Patients with Pneumonia in China, 2019, New England Journal of Medicine. 382 (2020) 727-733. https://doi.org/10.1056/nejmoa2001017.

[2] WHO Coronavirus Disease (COVID-19) Dashboard | WHO Coronavirus Disease (COVID-19) Dashboard, (n.d.). https://covid19.who.int/ (accessed January 8, 2021).

[3] Y.R. Guo, Q.D. Cao, Z.S. Hong, Y.Y. Tan, S.D. Chen, H.J. Jin, K. sen Tan, D.Y. Wang, Y. Yan, The origin, transmission and clinical therapies on coronavirus disease 2019 (COVID-19) outbreak- A n update on the status, Military Medical Research. 7 (2020). https://doi.org/10.1186/s40779-020-00240-0.

[4] I.T.S. Yu, Y. Li, T.W. Wong, W. Tam, A.T. Chan, J.H.W. Lee, D.Y.C. Leung, T. Ho, Evidence of Airborne Transmission of the Severe Acute Respiratory Syndrome Virus, New England Journal of Medicine. 350 (2004) 1731-1739. https://doi.org/10.1056/nejmoa032867. 
[5] J.A. Otter, C. Donskey, S. Yezli, S. Douthwaite, S.D. Goldenberg, D.J. Weber, Transmission of SARS and MERS coronaviruses and influenza virus in healthcare settings: The possible role of dry surface contamination, Journal of Hospital Infection. 92 (2016) 235-250.

https://doi.org/10.1016/j.jhin.2015.08.027.

[6] Y. Li, X. Huang, I.T.S. Yu, T.W. Wong, H. Qian, Role of air distribution in SARS transmission during the largest nosocomial outbreak in Hong Kong, Indoor Air. 15 (2005) 83-95. https://doi.org/10.1111/j.1600-0668.2004.00317.x.

[7] C. Rothe, M. Schunk, P. Sothmann, G. Bretzel, G. Froeschl, C. Wallrauch, T. Zimmer, V. Thiel, C. Janke, W. Guggemos, M. Seilmaier, C. Drosten, P. Vollmar, K. Zwirglmaier, S. Zange, R. Wölfel, M. Hoelscher, Transmission of 2019-nCoV Infection from an Asymptomatic Contact in Germany, New England Journal of Medicine. 382 (2020) 970-971.

https://doi.org/10.1056/nejmc2001468.

[8] G. Ye, H. Lin, S. Chen, S. Wang, Z. Zeng, W. Wang, S. Zhang, T. Rebmann, Y. Li, Z. Pan, Z. Yang, Y. Wang, F. Wang, Z. Qian, X. Wang, Environmental contamination of SARS-CoV-2 in healthcare premises, Journal of Infection. 81 (2020) e1-e5. https://doi.org/10.1016/j.jinf.2020.04.034.

[9] S.W.X. Ong, Y.K. Tan, P.Y. Chia, T.H. Lee, O.T. Ng, M.S.Y. Wong, K. Marimuthu, Air, Surface Environmental, and Personal Protective Equipment Contamination by Severe Acute Respiratory Syndrome Coronavirus 2 (SARSCoV-2) from a Symptomatic Patient, JAMA - Journal of the American Medical Association. 323 (2020) 1610-1612. https://doi.org/10.1001/jama.2020.3227.

[10] J. Cai, W. Sun, J. Huang, M. Gamber, J. Wu, G. He, Indirect virus transmission in cluster of COVID-19 cases, Wenzhou, China, 2020, Emerging Infectious Diseases. 26 (2020) 1343-1345. https://doi.org/10.3201/EID2606.200412.

[11] K. Dhama, S. Khan, R. Tiwari, S. Sircar, S. Bhat, Y.S. Malik, K.P. Singh, W. Chaicumpa, D.K. Bonilla-Aldana, A.J. Rodriguez-Morales, Coronavirus disease 2019-COVID-19, Clinical Microbiology Reviews. 33 (2020) 1-48. https://doi.org/10.1128/CMR.00028-20.

[12] N. van Doremalen, T. Bushmaker, D.H. Morris, M.G. Holbrook, A. Gamble, B.N. Williamson, A. Tamin, J.L. Harcourt, N.J. Thornburg, S.I. Gerber, J.O. Lloyd-Smith, E. de Wit, V.J. Munster, Aerosol and Surface Stability of SARSCoV-2 as Compared with SARS-CoV-1, New England Journal of Medicine. 382 (2020) 1564-1567. https://doi.org/10.1056/nejmc2004973.

[13] N. van Doremalen, T. Bushmaker, D.H. Morris, M.G. Holbrook, A. Gamble, B.N. Williamson, A. Tamin, J.L. Harcourt, N.J. Thornburg, S.I. Gerber, J.O. Lloyd-Smith, E. de Wit, V.J. Munster, Aerosol and Surface Stability of SARSCoV-2 as Compared with SARS-CoV-1, New England Journal of Medicine. 382 (2020) 1564-1567. https://doi.org/10.1056/nejmc2004973.

[14] A. Fears, W. Klimstra, P. Duprex, A. Hartman, S. Weaver, K. Plante, D. Mirchandani, J. Plante, P. Aguilar, D. Fernandez, A. Nalca, A. Totura, D. Dyer, B. Kearney, M. Lackemeyer, J.K. Bohannon, R. Johnson, R. Garry, D. Reed, C. Roy, Comparative dynamic aerosol efficiencies of three emergent coronaviruses and the unusual persistence of SARS-CoV-2 in aerosol suspensions, MedRxiv : The Preprint Server for Health Sciences. (2020). https://doi.org/10.1101/2020.04.13.20063784.

[15] A.W.H. Chin, J.T.S. Chu, M.R.A. Perera, K.P.Y. Hui, H.-L. Yen, M.C.W. Chan, M. Peiris, L.L.M. Poon, Stability of SARS-CoV-2 in different environmental 
conditions, The Lancet Microbe. 1 (2020) e10. https://doi.org/10.1016/s26665247(20)30003-3.

[16] H.A. Aboubakr, T.A. Sharafeldin, S.M. Goyal, Stability of SARS-CoV-2 and other coronaviruses in the environment and on common touch surfaces and the influence of climatic conditions: A review, Transboundary and Emerging Diseases. 00 (2020) 1-17. https://doi.org/10.1111/tbed.13707.

[17] H. Sakaguchi, K. Wada, J. Kajioka, M. Watanabe, R. Nakano, T. Hirose, H. Ohta, Y. Aizawa, Maintenance of influenza virus infectivity on the surfaces of personal protective equipment and clothing used in healthcare settings, Environmental Health and Preventive Medicine. 15 (2010) 344-349. https://doi.org/10.1007/s12199-010-0149-y.

[18] S.B. Kasloff, J.E. Strong, D. Funk, T. Cutts, Stability of SARS-CoV-2 on Critical Personal Protective Equipment, MedRxiv. (2020) 2020.06.11.20128884. https://doi.org/10.1101/2020.06.11.20128884.

[19] A.W.H. Chin, J.T.S. Chu, M.R.A. Perera, K.P.Y. Hui, H.-L. Yen, M.C.W. Chan, M. Peiris, L.L.M. Poon, Stability of SARS-CoV-2 in different environmental conditions, The Lancet Microbe. 1 (2020) e10. https://doi.org/10.1016/s26665247(20)30003-3.

[20] X. Xue, J.K. Ball, C. Alexander, M.R. Alexander, All Surfaces Are Not Equal in Contact Transmission of SARS-CoV-2, Matter. 3 (2020) 1433-1441. https://doi.org/10.1016/j.matt.2020.10.006.

[21] COVID19_4_claves.jpg $(1440 \times 1440)$, (n.d.). https://www.mscbs.gob.es/profesionales/saludPublica/ccayes/alertasActual/nCov/ img/COVID19_4_claves.jpg (accessed January 11, 2021).

[22] M.A. Quintana-Díaz, C.A. Aguilar-Salinas, UNIVERSAL MASKING DURING COVID-19 PANDEMIC - CURRENT EVIDENCE AND CONTROVERSIES, Revista de Investigacion Clinica; Organo Del Hospital de Enfermedades de La Nutricion. 72 (2020) 144-150. https://doi.org/10.24875/RIC.20000196.

[23] (No Title), (n.d.). https://apps.who.int/iris/bitstream/handle/10665/331493/WHO2019-nCoV-IPC_Masks-2020.2-eng.pdf (accessed January 11, 2021).

[24] (No Title), (n.d.). https://www.who.int/docs/default-source/documents/advice-onthe-use-of-masks-2019-ncov.pdf (accessed January 11, 2021).

[25] W.H. Organization, Advice on the use of masks in the context of COVID-19: interim guidance, 6 April 2020, World Health Organization, 2020.

[26] (No Title), (n.d.). https://coronavirus.gob.mx/wpcontent/uploads/2020/04/Recomendaciones_Uso_Correcto_Respirador.pdf (accessed January 11, 2021).

[27] Use Masks to Help Slow Spread / CDC, (n.d.). https:/www.cdc.gov/coronavirus/2019-ncov/prevent-getting-sick/diy-cloth-facecoverings.html (accessed January 11, 2021).

[28] S.E. Eikenberry, M. Mancuso, E. Iboi, T. Phan, K. Eikenberry, Y. Kuang, E. Kostelich, A.B. Gumel, To mask or not to mask: Modeling the potential for face mask use by the general public to curtail the COVID-19 pandemic, Infectious Disease Modelling. 5 (2020) 293-308. https://doi.org/10.1016/j.idm.2020.04.001.

[29] V.C.C. Cheng, S.C. Wong, V.W.M. Chuang, S.Y.C. So, J.H.K. Chen, S. Sridhar, K.K.W. To, J.F.W. Chan, I.F.N. Hung, P.L. Ho, K.Y. Yuen, The role of community-wide wearing of face mask for control of coronavirus disease 2019 (COVID-19) epidemic due to SARS-CoV-2, Journal of Infection. 81 (2020) 107114. https://doi.org/10.1016/j.jinf.2020.04.024. 
[30] D.P. Oran, E.J. Topol, Prevalence of Asymptomatic SARS-CoV-2 Infection : A Narrative Review, Annals of Internal Medicine. 173 (2020) 362-367. https://doi.org/10.7326/M20-3012.

[31] A. Kronbichler, D. Kresse, S. Yoon, K.H. Lee, M. Effenberger, J. il Shin, Asymptomatic patients as a source of COVID-19 infections: A systematic review and meta-analysis, International Journal of Infectious Diseases. 98 (2020) 180186. https://doi.org/10.1016/j.ijid.2020.06.052.

[32] H. Nishiura, T. Kobayashi, T. Miyama, A. Suzuki, S. mok Jung, K. Hayashi, R. Kinoshita, Y. Yang, B. Yuan, A.R. Akhmetzhanov, N.M. Linton, Estimation of the asymptomatic ratio of novel coronavirus infections (COVID-19), International Journal of Infectious Diseases. 94 (2020) 154-155. https://doi.org/10.1016/j.ijid.2020.03.020.

[33] Y. Bai, L. Yao, T. Wei, F. Tian, D.Y. Jin, L. Chen, M. Wang, Presumed Asymptomatic Carrier Transmission of COVID-19, JAMA - Journal of the American Medical Association. 323 (2020) 1406-1407. https://doi.org/10.1001/jama.2020.2565.

[34] L. Zou, F. Ruan, M. Huang, L. Liang, H. Huang, Z. Hong, J. Yu, M. Kang, Y. Song, J. Xia, Q. Guo, T. Song, J. He, H.-L. Yen, M. Peiris, J. Wu, SARS-CoV-2 Viral Load in Upper Respiratory Specimens of Infected Patients, New England Journal of Medicine. 382 (2020) 1177-1179. https://doi.org/10.1056/nejmc2001737.

[35] A. Kimball, K.M. Hatfield, M. Arons, A. James, J. Taylor, K. Spicer, A.C. Bardossy, L.P. Oakley, S. Tanwar, Z. Chisty, J.M. Bell, M. Methner, J. Harney, J.R. Jacobs, C.M. Carlson, H.P. McLaughlin, N. Stone, S. Clark, C. BrostromSmith, L.C. Page, M. Kay, J. Lewis, D. Russell, B. Hiatt, J. Gant, J.S. Duchin, T.A. Clark, M.A. Honein, S.C. Reddy, J.A. Jernigan, A. Baer, L.M. Barnard, E. Benoliel, M.S. Fagalde, J. Ferro, H.G. Smith, E. Gonzales, N. Hatley, G. Hatt, M. Hope, M. Huntington-Frazier, V. Kawakami, J.L. Lenahan, M.D. Lukoff, E.B. Maier, S. McKeirnan, P. Montgomery, J.L. Morgan, L.A. Mummert, S. Pogosjans, F.X. Riedo, L. Schwarcz, D. Smith, S. Stearns, K.J. Sykes, H. Whitney, H. Ali, M. Banks, A. Balajee, E.J. Chow, B. Cooper, D.W. Currie, J. Dyal, J. Healy, M. Hughes, T.M. McMichael, L. Nolen, C. Olson, A.K. Rao, K. Schmit, N.G. Schwartz, F. Tobolowsky, R. Zacks, S. Zane, Asymptomatic and Presymptomatic SARS-CoV-2 Infections in Residents of a Long-Term Care Skilled Nursing Facility - King County, Washington, March 2020, MMWR. Morbidity and Mortality Weekly Report. 69 (2020) 377-381. https://doi.org/10.15585/mmwr.mm6913e1.

[36] A. Hussain, T. Singhal, S. EL-Hasani, Extent of infectious SARS-CoV-2 aerosolisation as a result of oesophagogastroduodenoscopy or colonoscopy, British Journal of Hospital Medicine. 81 (2020). https://doi.org/10.12968/hmed.2020.0348.

[37] L. Morawska, J. Cao, Airborne transmission of SARS-CoV-2: The world should face the reality, Environment International. 139 (2020). https://doi.org/10.1016/j.envint.2020.105730.

[38] L. Setti, F. Passarini, G. de Gennaro, P. Barbieri, M.G. Perrone, M. Borelli, J. Palmisani, A. di Gilio, P. Piscitelli, A. Miani, Airborne transmission route of covid-19: Why 2 meters/ 6 feet of inter-personal distance could not be enough, International Journal of Environmental Research and Public Health. 17 (2020). https://doi.org/10.3390/ijerph17082932. 
[39] K.R. Melayil, S.K. Mitra, Wetting, Adhesion, and Droplet Impact on Face Masks, Langmuir. 37 (2021) 2810-2815. https://doi.org/10.1021/acs.langmuir.0c03556.

[40] COVID-19: WHY WE SHOULD ALL WEAR MASKS — THERE IS NEW SCIENTIFIC RATIONALE | by Sui Huang | Medium, (n.d.).

https://medium.com/@Cancerwarrior/covid-19-why-we-should-all-wear-masksthere-is-new-scientific-rationale-280e08ceee71 (accessed February 9, 2021).

[41] Y. Li, H. Qian, J. Hang, X. Chen, L. Hong, P. Liang, J. Li, S. Xiao, J. Wei, L. Liu, M. Kang, Evidence for probable aerosol transmission of SARS-CoV-2 in a poorly ventilated restaurant, MedRxiv. (2020) 2020.04.16.20067728. https://doi.org/10.1101/2020.04.16.20067728.

[42] (No Title), (n.d.). https://www.who.int/docs/default-source/coronaviruse/whochina-joint-mission-on-covid-19-final-report.pdf (accessed January 11, 2021).

[43] M. Day, Covid-19: identifying and isolating asymptomatic people helped eliminate virus in Italian village, BMJ (Clinical Research Ed.). 368 (2020) m1165. https://doi.org/10.1136/bmj.m1165.

[44] M. Day, Covid-19: four fifths of cases are asymptomatic, China figures indicate, BMJ (Clinical Research Ed.). 369 (2020) m1375. https://doi.org/10.1136/bmj.m1375.

[45] Z. Zhang, D. Ji, H. He, S. Ramakrishna, Electrospun ultrafine fibers for advanced face masks, Materials Science and Engineering R: Reports. 143 (2021) 100594. https://doi.org/10.1016/j.mser.2020.100594.

[46] Z. Tang, N. Kong, X. Zhang, Y. Liu, P. Hu, S. Mou, P. Liljeström, J. Shi, W. Tan, J.S. Kim, Y. Cao, R. Langer, K.W. Leong, O.C. Farokhzad, W. Tao, A materials-science perspective on tackling COVID-19, Nature Reviews Materials. 5 (2020) 847-860. https://doi.org/10.1038/s41578-020-00247-y.

[47] E.V.R. Campos, A.E.S. Pereira, J.L. de Oliveira, L.B. Carvalho, M. GuilgerCasagrande, R. de Lima, L.F. Fraceto, How can nanotechnology help to combat COVID-19? Opportunities and urgent need, Journal of Nanobiotechnology. 18 (2020) 125. https://doi.org/10.1186/s12951-020-00685-4.

[48] M.C. Sportelli, M. Izzi, E.A. Kukushkina, S.I. Hossain, R.A. Picca, N. Ditaranto, N. Cioff, Can nanotechnology and materials science help the fight against sarscov-2?, Nanomaterials. 10 (2020) 802. https://doi.org/10.3390/nano10040802.

[49] P. Ranjan, V. Thomas, P. Kumar, 2D materials as a diagnostic platform for the detection and sensing of the SARS-CoV-2 virus: a bird's-eye view, Journal of Materials Chemistry B. 9 (2021) 4608-4619. https://doi.org/10.1039/d1tb00071c.

[50] Mohd.A. Sadique, S. Yadav, P. Ranjan, S. Verma, S.T. Salammal, Mohd.A. Khan, A. Kaushik, R. Khan, High-performance antiviral nano-systems as a shield to inhibit viral infections: SARS-CoV-2 as a model case study, Journal of Materials Chemistry B. 9 (2021) 4620-4642. https://doi.org/10.1039/d1 tb00472g.

[51] V.M. de O. Cardoso, B.J. Moreira, E.J. Comparetti, I. Sampaio, L.M.B. Ferreira, P.M.P. Lins, V. Zucolotto, Is Nanotechnology Helping in the Fight Against COVID-19?, Frontiers in Nanotechnology. 2 (2020) 588915. https://doi.org/10.3389/fnano.2020.588915.

[52] G. Pullangott, U. Kannan, G. S., D.V. Kiran, S.M. Maliyekkal, A comprehensive review on antimicrobial face masks: An emerging weapon in fighting pandemics, RSC Advances. 11 (2021) 6544-6576. https://doi.org/10.1039/d0ra10009a.

[53] S. Adanur, A. Jayswal, Filtration mechanisms and manufacturing methods of face masks: An overview, Journal of Industrial Textiles. (2020). https://doi.org/10.1177/1528083720980169. 
[54] W.A. Abbas, B.S. Shaheen, L.G. Ghanem, I.M. Badawy, M.M. Abodouh, S.M. Abdou, S. Zada, N.K. Allam, Cost-Effective Face Mask Filter Based on Hybrid Composite Nanofibrous Layers with High Filtration Efficiency., Langmuir: The ACS Journal of Surfaces and Colloids. (2021). https://doi.org/10.1021/acs.langmuir.1c00926.

[55] ASTM International, ASTM F2100 - 19e1 Standard Specification for Performance of Materials Used in Medical Face Masks, (2019). www.astm.org.

[56] M.H. Chua, W. Cheng, S.S. Goh, J. Kong, B. Li, J.Y.C. Lim, L. Mao, S. Wang, K. Xue, L. Yang, E. Ye, K. Zhang, W.C.D. Cheong, B.H. Tan, Z. Li, B.H. Tan, X.J. Loh, Face Masks in the New COVID-19 Normal: Materials, Testing, and Perspectives, Research. 2020 (2020) 1-40. https://doi.org/10.34133/2020/7286735.

[57] UNE-EN ISO 10993: Biological evaluation of medical devices, (2010).

[58] (No Title), (n.d.). https://www.mincotur.gob.es/es-es/COVID19/industria/GuiaFabricacionEpis/Modelos\%20de\%20Mascarillas\%20Higienicas $\% 20$ Desarrollados\%20por\%20AITEX/AITEX_mascarillas_higienicas_no_reutili zables.pdf (accessed February 8, 2021).

[59] (No Title), (n.d.).

https://www.mscbs.gob.es/en/profesionales/saludPublica/ccayes/alertasActual/nC ov/documentos/030520_GUIA_COMPRA_MASCARILLAS.pdf (accessed February 1, 2021).

[60] (No Title), (n.d.). https:/gruposdetrabajo.sefh.es/gps/images/stories/documentos/COVID19_HIGIENICAS_MASCARILLAS.pdf (accessed February 1, 2021).

[61] ESPECIFICACION UNE 0064-1:2020 Mascarillas higiénicas no reuti..., (n.d.). https://www.une.org/encuentra-tu-norma/busca-tunorma/norma/?c $=$ N0063626\%20y\%202020b (accessed February 1, 2021).

[62] ESPECIFICACION UNE 0064-2:2020 Mascarillas higiénicas no reuti..., (n.d.). https://www.une.org/encuentra-tu-norma/busca-tu-norma/norma/?c=N0063627 (accessed February 1, 2021).

[63] ESPECIFICACION UNE 0065:2020 Mascarillas higiénicas reutilizab..., (n.d.). https://www.une.org/encuentra-tu-norma/busca-tunorma/norma/?c=N0063661\%C2\%A0 (accessed February 1, 2021).

[64] N95 vs FFP3 \& FFP2 masks - what's the difference?, (n.d.). https://fastlifehacks.com/n95-vs-ffp/\#Surgical_Masks (accessed February 8, 2021).

[65] Y. Pu, J. Zheng, F. Chen, Y. Long, H. Wu, Q. Li, S. Yu, X. Wang, X. Ning, Preparation of Polypropylene Micro and Nanofibers by Electrostatic-Assisted Melt Blown and Their Application, Polymers. 10 (2018) 959. https://doi.org/10.3390/polym10090959.

[66] J.E. Coia, L. Ritchie, A. Adisesh, C. Makison Booth, C. Bradley, D. Bunyan, G. Carson, C. Fry, P. Hoffman, D. Jenkins, N. Phin, B. Taylor, J.S. Nguyen-VanTam, M. Zuckerman, Guidance on the use of respiratory and facial protection equipment, Journal of Hospital Infection. 85 (2013) 170-182. https://doi.org/10.1016/j.jhin.2013.06.020.

[67] C.J. Kähler, R. Hain, Fundamental protective mechanisms of face masks against droplet infections, Journal of Aerosol Science. 148 (2020) 105617. https://doi.org/10.1016/j.jaerosci.2020.105617.

[68] A. Santarsiero, P. Ciambelli, G. Donsì, F. Quadrini, R. Briancesco, D. D'alessandro, G.M. Fara, Face masks. Technical, technological and func-tional 
characteristics and hygienic-sanitary aspects related to the use of filtering mask in the community, Ann Ig. 32 (2020) 472-520.

https://doi.org/10.7416/ai.2020.2371.

[69] UNE-EN 14683:2019+AC:2019 Mascarillas quirúrgicas. Requisitos ..., (n.d.). https://www.une.org/encuentra-tu-norma/busca-tu-

norma/norma/?c=N0062987\%20/ (accessed January 25, 2021).

[70] UNE-EN ISO 10993-1:2010 Evaluación biológica de productos sani..., (n.d.). https://www.une.org/encuentra-tu-norma/busca-tu-norma/norma?c=N0045143 (accessed January 25, 2021).

[71] UNE-EN ISO 11737-1:2018 Esterilización de productos para la sa..., (n.d.). https://www.une.org/encuentra-tu-norma/busca-tu-norma/norma/?c=N0061265 (accessed January 25, 2021).

[72] UNE-EN ISO 15223-1:2017 Productos sanitarios. Símbolos a utili..., (n.d.). https://www.une.org/encuentra-tu-norma/busca-tu-norma/norma?c=N0058117 (accessed January 25, 2021).

[73] UNE-EN 1041:2009+A1:2014 Información proporcionada por el fabr..., (n.d.). https://www.une.org/encuentra-tu-norma/busca-tu-norma/norma?c=N0052627 (accessed January 25, 2021).

[74] K.R. Melayil, S.K. Mitra, Wetting, Adhesion, and Droplet Impact on Face Masks, Langmuir. 37 (2021) 2810-2815. https://doi.org/10.1021/acs.langmuir.0c03556.

[75] S. Bae, M.C. Kim, J.Y. Kim, H.H. Cha, J.S. Lim, J. Jung, M.J. Kim, D.K. Oh, M.K. Lee, S.H. Choi, M. Sung, S.B. Hong, J.W. Chung, S.H. Kim, Retraction: Effectiveness of Surgical and Cotton Masks in Blocking SARS-CoV-2: A Controlled Comparison in 4 Patients (Annals of internal medicine (2020)), Annals of Internal Medicine. 173 (2020) W22-W23. https://doi.org/10.7326/M20-1342.

[76] T. Oberg, L.M. Brosseau, Surgical mask filter and fit performance, American Journal of Infection Control. 36 (2008) 276-282. https://doi.org/10.1016/j.ajic.2007.07.008.

[77] S.-A. Lee, S.A. Grinshpun, T. Reponen, Respiratory Performance Offered by N95 Respirators and Surgical Masks: Human Subject Evaluation with $\mathrm{NaCl}$ Aerosol Representing Bacterial and Viral Particle Size Range, The Annals of Occupational Hygiene. 52 (2008) 177-185. https://doi.org/10.1093/annhyg/men005.

[78] T.G. Ksiazek, D. Erdman, C.S. Goldsmith, S.R. Zaki, T. Peret, S. Emery, S. Tong, C. Urbani, J.A. Comer, W. Lim, P.E. Rollin, S.F. Dowell, A.-E. Ling, C.D. Humphrey, W.-J. Shieh, J. Guarner, C.D. Paddock, P. Rota, B. Fields, J. DeRisi, J.-Y. Yang, N. Cox, J.M. Hughes, J.W. LeDuc, W.J. Bellini, L.J. Anderson, A Novel Coronavirus Associated with Severe Acute Respiratory Syndrome, New England Journal of Medicine. 348 (2003) 1953-1966. https://doi.org/10.1056/NEJMoa030781.

[79] S. Executive, Health and Safety Executive HSG53 (Fourth edition, published 2013). Respiratory protective equipment at work A practical guide Health and Safety Executive, 2013. www.nationalarchives.gov.uk/doc/opengovernmentlicence/, (accessed February 4, 2021).

[80] Material para mascarillas y tejido no tejido sanitario, (n.d.). http://blog.fdtecsl.com/material-para-mascarillas-tejido-no-tejido-sanitario (accessed February 8, 2021). 
[81] (No Title), (n.d.). https://www.mincotur.gob.es/es-es/COVID-

19/industria/GuiaFabricacionEpis/Mascarillas\%20de $\% 20$ proteccion $\% 20$ respirato ria\%20EPI/6_Proceso_de_fabricacion_habitual_de_mascarillas_EPIs_v3.0.pdf (accessed February 8, 2021).

[82] Mascarillas: ¿qué tipos existen y qué requisitos deben cumplir?, (n.d.). https://www.sefap.org/2020/04/27/mascarillas-que-tipos-existen-y-querequisitos-deben-cumplir/ (accessed February 4, 2021).

[83] EUR-Lex - 32016R0425 - EN - EUR-Lex, (n.d.). https://eur-lex.europa.eu/legalcontent/ES/TXT/?uri=CELEX\%3A32016R0425 (accessed February 4, 2021).

[84] UNE-EN 149:2001+A1:2010 Dispositivos de protección respiratori..., (n.d.). https://www.une.org/encuentra-tu-norma/busca-tu-norma/norma?c=N0044643 (accessed February 4, 2021).

[85] (No Title), (n.d.). https://www.portalfarma.com/Profesionales/campanaspf/Asesoramiento-saludpublica/infeccion-coronavirus-2019-nCoV/Documents/mascarillascoronavirus.pdf (accessed February 10, 2021).

[86] (No Title), (n.d.). https://www.uab.edu/ehs/images/docs/ss/ss_2016-10bdifference-between-dust-mask-and-respirator.pdf (accessed February 10, 2021).

[87] Dust Mask vs. Respirator | Environmental Health \& Safety | Michigan State University, (n.d.). https://ehs.msu.edu/occ/respirator/dustmask-vs-resp.html (accessed February 10, 2021).

[88] Fiche Pratique de Sécurité, (n.d.). https://www.esstinrs.fr/3rb/ressources/ed105.pdf (accessed February 4, 2021).

[89] L.A. Pompeii, C.S. Kraft, E.A. Brownsword, M.A. Lane, E. Benavides, J. Rios, L.J. Radonovich, Training and Fit Testing of Health Care Personnel for Reusable Elastomeric Half-Mask Respirators Compared with Disposable N95 Respirators, JAMA - Journal of the American Medical Association. 323 (2020) 1849-1852. https://doi.org/10.1001/jama.2020.4806.

[90] J.E. Coia, L. Ritchie, A. Adisesh, C. Makison Booth, C. Bradley, D. Bunyan, G. Carson, C. Fry, P. Hoffman, D. Jenkins, N. Phin, B. Taylor, J.S. Nguyen-VanTam, M. Zuckerman, Guidance on the use of respiratory and facial protection equipment, Journal of Hospital Infection. 85 (2013) 170-182. https://doi.org/10.1016/j.jhin.2013.06.020.

[91] S.A. Grinshpun, H. Haruta, R.M. Eninger, T. Reponen, R.T. McKay, S.A. Lee, Performance of an N95 filtering facepiece particulate respirator and a surgical mask during human breathing: Two pathways for particle penetration, Journal of Occupational and Environmental Hygiene. 6 (2009) 593-603. https://doi.org/10.1080/15459620903120086.

[92] D. Lepelletier, B. Grandbastien, S. Romano-Bertrand, S. Aho, C. Chidiac, J.F. Géhanno, F. Chauvin, What face mask for what use in the context of the COVID19 pandemic? The French guidelines, Journal of Hospital Infection. 105 (2020) 414-418. https://doi.org/10.1016/j.jhin.2020.04.036.

[93] KN95 Mask, (n.d.). https://www.terrycralle.com/kn95-mask/ (accessed June 7, 2021).

[94] M.A. Hasan, A. Carmel Mary Esther, A. Dey, A.K. Mukhopadhyay, A review on coronavirus survivability on material's surfaces: present research scenarios, technologies and future directions, Surface Engineering. 36 (2020) 1226-1239. https://doi.org/10.1080/02670844.2020.1833277.

[95] K. O’dowd, K.M. Nair, P. Forouzandeh, S. Mathew, J. Grant, R. Moran, J. Bartlett, J. Bird, S.C. Pillai, materials Face Masks and Respirators in the Fight 
Against the COVID-19 Pandemic: A Review of Current Materials, Advances and Future Perspectives, (n.d.). https://doi.org/10.3390/ma13153363.

[96] K. Biedermann, Anti-viral face mask and filter material, 2009.

[97] K. Biedermann, ( 12 ) Patent Application Publication ( 10 ) Pub . No .: US 2009 / 0205106A1, 1 (2008) 1-6.

[98] G. Tiliket, D. le Sage, V. Moules, M. Rosa-Calatrava, B. Lina, J.M. Valleton, Q.T. Nguyen, L. Lebrun, A new material for airborne virus filtration, Chemical Engineering Journal. 173 (2011) 341-351. https://doi.org/10.1016/j.cej.2011.07.059.

[99] A.M. Davison, Pathogen inactivation and filtration efficacy of a new antimicrobial and anti-viral surgical facemask and N95 against dentistry-associated microorganisms, n.d.

[100] F.S. Quan, I. Rubino, S.H. Lee, B. Koch, H.J. Choi, Universal and reusable virus deactivation system for respiratory protection, Scientific Reports. 7 (2017) 1-10. https://doi.org/10.1038/srep39956.

[101] A biomedical engineer created a mask coated in salt that he says could neutralize viruses like the coronavirus in 5 minutes | Business Insider India, (n.d.). https://www.businessinsider.in/science/news/a-biomedical-engineer-created-amask-coated-in-salt-that-he-says-could-neutralize-viruses-like-the-coronavirusin-5-minutes/articleshow/74029912.cms (accessed June 7, 2021).

[102] X. Shan, H. Zhang, C. Liu, L. Yu, Y. Di, X. Zhang, L. Dong, Z. Gan, Reusable Self-Sterilization Masks Based on Electrothermal Graphene Filters, ACS Applied Materials and Interfaces. 12 (2020) 56579-56586. https://doi.org/10.1021/acsami.0c16754.

[103] S. Choi, H. Jeon, M. Jang, H. Kim, G. Shin, J.M. Koo, M. Lee, H.K. Sung, Y. Eom, H.S. Yang, J. Jegal, J. Park, D.X. Oh, S.Y. Hwang, Biodegradable, Efficient, and Breathable Multi-Use Face Mask Filter, Advanced Science. 8 (2021) 2003155. https://doi.org/10.1002/advs.202003155.

[104] Z. Lin, Z. Wang, X. Zhang, D. Diao, Superhydrophobic, photo-sterilize, and reusable mask based on graphene nanosheet-embedded carbon (GNEC) film, Nano Research. 14 (2021) 1110-1115. https://doi.org/10.1007/s12274-020-31581.

[105] H. Zhong, Z. Zhu, J. Lin, C.F. Cheung, V.L. Lu, F. Yan, C.Y. Chan, G. Li, Reusable and Recyclable Graphene Masks with Outstanding Superhydrophobic and Photothermal Performances, ACS Nano. 14 (2020) 6213-6221. https://doi.org/10.1021/acsnano.0c02250.

[106] M. Martí, A. Tuñón-Molina, F. Lillelund Aachmann, Y. Muramoto, T. Noda, K. Takayama, Á. Serrano-Aroca, Protective face mask filter capable of inactivating SARS-CoV-2, and methicillin-resistant Staphylococcus aureus and Staphylococcus epidermidis, BioRxiv. (2020) 2020.11.24.396028. https://doi.org/10.1101/2020.11.24.396028.

[107] A. Pandey, A.N. Nikam, S.P. Mutalik, G. Fernandes, A.B. Shreya, B. Singh Padya, R. Raychaudhuri, S. Kulkarni, R. Prassl, S. Subramanian, A. Korde, S. Mutalik, Architectured Therapeutic and Diagnostic Nanoplatforms for Combating SARS-CoV-2: Role of Inorganic, Organic, and Radioactive Materials, Cite This: ACS Biomater. Sci. Eng. 7 (2021) 31-54. https://doi.org/10.1021/acsbiomaterials.0c01243.

[108] J. Hodek, V. Zajícová, I. Lovetinská-Šlamborová, I. Stibor, J. Müllerová, J. Weber, Protective hybrid coating containing silver, copper and zinc cations 
effective against human immunodeficiency virus and other enveloped viruses, BMC Microbiology. 16 (2016) 1-12. https://doi.org/10.1186/s12866-016-0675-x.

[109] G. Borkow, Using Copper to Fight Microorganisms, Current Chemical Biology. 6 (2012) 93-103. https://doi.org/10.2174/187231312801254723.

[110] G. Borkow, S.S. Zhou, T. Page, J. Gabbay, A novel anti-influenza copper oxide containing respiratory face mask, PLoS ONE. 5 (2010). https://doi.org/10.1371/journal.pone.0011295.

[111] Mask use in the context of COVID-19, (n.d.). https://www.who.int/publications/i/item/advice-on-the-use-of-masks-in-thecommunity-during-home-care-and-in-healthcare-settings-in-the-context-of-thenovel-coronavirus-(2019-ncov)-outbreak (accessed February 22, 2021).

[112] S. Jung, E.Y. Byeon, D.G. Kim, D.G. Lee, S. Ryoo, S. Lee, C.W. Shin, H.W. Jang, J.Y. Yang, H.J. Kim, S. Lee, Copper-coated polypropylene filter face mask with SARS-COV-2 antiviral ability, Polymers. 13 (2021) 1367. https://doi.org/10.3390/polym13091367.

[113] A. Shibata, M. Ishigami, N. Takeuchi, Patent Application Publication, 1 (2012).

[114] S. Podder, S. Halder, A. Roychowdhury, D. Das, C.K. Ghosh, Superb hydroxyl radical-mediated biocidal effect induced antibacterial activity of tuned $\mathrm{ZnO} /$ chitosan type II heterostructure under dark, Journal of Nanoparticle Research. 18 (2016) 1-12. https://doi.org/10.1007/s11051-016-3605-9.

[115] V. Lakshmi Prasanna, R. Vijayaraghavan, Insight into the Mechanism of Antibacterial Activity of ZnO: Surface Defects Mediated Reactive Oxygen Species even in the Dark, Langmuir. 31 (2015) 9155-9162. https://doi.org/10.1021/acs.langmuir.5b02266.

[116] M. Assis, L.G.P. Simoes, G.C. Tremiliosi, D. Coelho, D.T. Minozzi, R.I. Santos, D.C.B. Vilela, J.R. do Santos, L.K. Ribeiro, I.L.V. Rosa, L.H. Mascaro, J. Andrés, E. Longo, Sio2-ag composite as a highly virucidal material: A roadmap that rapidly eliminates sars-cov-2, Nanomaterials. 11 (2021) 1-19. https://doi.org/10.3390/nano11030638.

[117] Y.N. Chen, Y.H. Hsueh, C. te Hsieh, D.Y. Tzou, P.L. Chang, Antiviral activity of graphene-silver nanocomposites against non-enveloped and enveloped viruses, International Journal of Environmental Research and Public Health. 13 (2016). https://doi.org/10.3390/ijerph13040430.

[118] F. de Maio, V. Palmieri, G. Babini, A. Augello, I. Palucci, G. Perini, A. Salustri, M. de Spirito, M. Sanguinetti, G. Delogu, L. Giorgia Rizzi, G. Cesareo, P. SoonShiong, M. Sali, M. Papi, Graphene nanoplatelet and Graphene oxide functionalization of face mask materials inhibits infectivity of trapped SARSCoV-2, MedRxiv. (2020) 2020.09.16.20194316. https://doi.org/10.1101/2020.09.16.20194316.

[119] V. Palmieri, F. Bugli, M.C. Lauriola, M. Cacaci, R. Torelli, G. Ciasca, C. Conti, M. Sanguinetti, M. Papi, M. de Spirito, Bacteria Meet Graphene: Modulation of Graphene Oxide Nanosheet Interaction with Human Pathogens for Effective Antimicrobial Therapy, ACS Biomaterials Science and Engineering. 3 (2017) 619-627. https://doi.org/10.1021/acsbiomaterials.6b00812.

[120] V. Palmieri, M. Carmela Lauriola, G. Ciasca, C. Conti, M. de Spirito, M. Papi, The graphene oxide contradictory effects against human pathogens, Nanotechnology. 28 (2017). https://doi.org/10.1088/1361-6528/aa6150.

[121] Z. Song, X. Wang, G. Zhu, Q. Nian, H. Zhou, D. Yang, C. Qin, R. Tang, Virus capture and destruction by label-free graphene oxide for detection and 
disinfection applications, Small. 11 (2015) 1771-1776.

https://doi.org/10.1002/smll.201401706.

[122] R. Frost, G.E. Jönsson, D. Chakarov, S. Svedhem, B. Kasemo, Graphene oxide and lipid membranes: Interactions and nanocomposite structures, Nano Letters. 12 (2012) 3356-3362. https://doi.org/10.1021/nl203107k.

[123] L. Rui, J. Liu, J. Li, Y. Weng, Y. Dou, B. Yuan, K. Yang, Y. Ma, Reduced graphene oxide directed self-assembly of phospholipid monolayers in liquid and gel phases, Biochimica et Biophysica Acta - Biomembranes. 1848 (2015) 12031211. https://doi.org/10.1016/j.bbamem.2015.02.018.

[124] S. Kumar, M. Karmacharya, S.R. Joshi, O. Gulenko, J. Park, G.H. Kim, Y.K. Cho, Photoactive Antiviral Face Mask with Self-Sterilization and Reusability, Nano Letters. 21 (2021) 337-343. https://doi.org/10.1021/acs.nanolett.0c03725.

[125] M. Catel-Ferreira, H. Tnani, C. Hellio, P. Cosette, L. Lebrun, Antiviral effects of polyphenols: Development of bio-based cleaning wipes and filters, Journal of Virological Methods. 212 (2015) 1-7. https://doi.org/10.1016/j.jviromet.2014.10.008.

[126] U.A. Ashfaq, M.S. Masoud, Z. Nawaz, S. Riazuddin, Glycyrrhizin as antiviral agent against Hepatitis C Virus, 2011. https://doi.org/10.1186/1479-5876-9-112.

[127] J. Cinatl, B. Morgenstern, G. Bauer, P. Chandra, H. Rabenau, H.W. Doerr, Glycyrrhizin, an active component of liquorice roots, and replication of SARSassociated coronavirus, Lancet. 361 (2003) 2045-2046. https://doi.org/10.1016/S0140-6736(03)13615-X.

[128] C. Bailly, G. Vergoten, Glycyrrhizin: An alternative drug for the treatment of COVID-19 infection and the associated respiratory syndrome?, Pharmacology and Therapeutics. 214 (2020) 107618. https://doi.org/10.1016/j.pharmthera.2020.107618.

[129] M.A. Chowdhury, M.B.A. Shuvho, M.A. Shahid, A.K.M.M. Haque, M.A. Kashem, S.S. Lam, H.C. Ong, M.A. Uddin, M. Mofijur, Prospect of biobased antiviral face mask to limit the coronavirus outbreak, Environmental Research. 192 (2021) 110294. https://doi.org/10.1016/j.envres.2020.110294.

[130] E. Passaglia, B. Campanella, S. Coiai, F. Cicogna, A. Carducci, M. Verani, I. Federigi, B. Casini, B. Tuvo, E. Bramanti, Agri-Food Extracts Effectiveness in Improving Antibacterial and Antiviral Properties of Face Masks: A Proof-ofConcept Study, ChemistrySelect. 6 (2021) 2288-2297. https://doi.org/10.1002/slct.202004678.

[131] J. Zhang, B. Li, L. Wu, A. Wang, Facile preparation of durable and robust superhydrophobic textiles by dip coating in nanocomposite solution of organosilanes, Chemical Communications. 49 (2013) 11509-11511. https://doi.org/10.1039/c3cc43238f.

[132] Antimicrobial resistance, (n.d.). https://www.who.int/health-topics/antimicrobialresistance (accessed February 20, 2021).

[133] M. Chan-Yeung, Severe acute respiratory syndrome (SARS) and healthcare workers, International Journal of Occupational and Environmental Health. 10 (2004) 421-427. https://doi.org/10.1179/oeh.2004.10.4.421.

[134] S. Behzadinasab, A. Chin, M. Hosseini, L. Poon, W.A. Ducker, A Surface Coating that Rapidly Inactivates SARS-CoV-2, ACS Applied Materials and Interfaces. 12 (2020) 34723-34727. https://doi.org/10.1021/acsami.0c11425.

[135] Y.N. Chen, Y.H. Hsueh, C. te Hsieh, D.Y. Tzou, P.L. Chang, Antiviral activity of graphene-silver nanocomposites against non-enveloped and enveloped viruses, 
International Journal of Environmental Research and Public Health. 13 (2016). https://doi.org/10.3390/ijerph13040430.

[136] Á. Serrano-Aroca, K. Takayama, A. Tuñón-Molina, M. Seyran, S.S. Hassan, P. Pal Choudhury, V.N. Uversky, K. Lundstrom, P. Adadi, G. Palù, A.A.A. Aljabali, G. Chauhan, R. Kandimalla, M.M. Tambuwala, A. Lal, T.M. Abd ElAziz, S. Sherchan, D. Barh, E.M. Redwan, N.G. Bazan, Y.K. Mishra, B.D. Uhal, A. Brufsky, Carbon-Based Nanomaterials: Promising Antiviral Agents to Combat COVID-19 in the Microbial-Resistant Era, ACS Nano. (2021). https://doi.org/10.1021/acsnano.1c00629.

[137] S.K. Sharma, S.K. Shukla, D.N. Vaid, SHELLAC - STRUCTURE, CHARACTERISTICS \& MODIFICATION., Defence Science Journal. 33 (1983) 261-271. https://doi.org/10.14429/dsj.33.6181.

[138] Y. Farag, C.S. Leopold, Physicochemical Properties of Various Shellac Types, (n.d.). https://doi.org/10.14227/DT160209P33.

[139] A.R. Patel, Functional and Engineered Colloids from Edible Materials for Emerging Applications in Designing the Food of the Future, Advanced Functional Materials. 30 (2020) 1806809. https://doi.org/10.1002/adfm.201806809.

[140] M. Hans, A. Erbe, S. Mathews, Y. Chen, M. Solioz, F. Mücklich, Role of copper oxides in contact killing of bacteria, Langmuir. 29 (2013) 16160-16166. https://doi.org/10.1021/la404091z.

[141] Y.A. Wu, I. McNulty, C. Liu, K.C. Lau, Q. Liu, A.P. Paulikas, C.J. Sun, Z. Cai, J.R. Guest, Y. Ren, V. Stamenkovic, L.A. Curtiss, Y. Liu, T. Rajh, Facetdependent active sites of a single $\mathrm{Cu} 2 \mathrm{O}$ particle photocatalyst for $\mathrm{CO} 2$ reduction to methanol, Nature Energy. 4 (2019) 957-968. https://doi.org/10.1038/s41560019-0490-3.

[142] A. Ananth, S. Dharaneedharan, M.S. Heo, Y.S. Mok, Copper oxide nanomaterials: Synthesis, characterization and structure-specific antibacterial performance, Chemical Engineering Journal. 262 (2015) 179-188. https://doi.org/10.1016/j.cej.2014.09.083.

[143] S. Mallakpour, E. Azadi, C.M. Hussain, Fight against COVID-19 pandemic with the help of carbon-based nanomaterials, New Journal of Chemistry. 45 (2021) 8832-8846. https://doi.org/10.1039/d1nj01333e.

[144] S.N. Chirkov, The antiviral activity of chitosan (review), Applied Biochemistry and Microbiology. 38 (2002) 1-8. https://doi.org/10.1023/A:1013206517442.

[145] Y. Andres, L. Giraud, C. Gerente, P. le Cloirec, Antibacterial effects of Chitosan powder: Mechanisms of action, Environmental Technology. 28 (2007) 13571363. https://doi.org/10.1080/09593332808618893. 